\title{
The Role of Organ Transplantation in Pediatrics
}

\author{
Thomas E. Starzl, M.D., Thomas L. Marchioro, M.D., Ken A. Porter, M.D., Tanous D. Faris, \\ M.D., and Thomas A. Carey, M.D. \\ Departments of Surgery, University of Colorado School of Medicine and the Veterans \\ Administration Hospital, Denver; and the Department of Pathology, St. Mary's Hospital and \\ Medical School, London, England
}

The greatest application of whole organ, transplantation may prove to be in the field of pediatric medicine, in which the progression of disease is often due to failure of a single organ system. Under these circumstances the provision of good renal or hepatic or cardiac function might be expected to restore normal health. In adult patients comparable problems are frequently and sometimes unexpectedly complicated by disorders other than those to which treatment was originally directed; examples are known of myocardial infarction, stroke or even malignancy in older patients who had been successfully treated with renal homotransplantation.

In this communication an attempt will be made to define the potential usefulness of homografting procedures in infants and children, excluding cases of identical twins. Although experience in all age groups and in laboratory animals will be alluded to, the principal emphasis will be directed to the medical, technical, psychologic and sociologic problems encountered in treating a series of patients at or below the age of 18 years. Discussion will be limited to transplantation of the kidney and the liver. Success with the former organ has already been achieved to a previously unhoped-for degree. Findings in the laboratory suggest that comparable results are at least theoretically attainable with the liver.

\section{Renal Transplantation}

During the last three years 22 pediatric patients were treated at the University of Colorado Medical Center with homotransplantation of the kidney (Table 9). Seven were 12 years or younger at the time of operation, and 15 were from 13 to 18 years. The original renal disease was chronic glomerulonephritis in 18 cases, polycystic disease in one and end-stage pyelonephritis in the other three. The life expectancy without either dialysis or homotransplantation was only a few days or weeks in each instance except one. Most of the patients had had a chronic debilitating illness, but in the minority clinically evident symptoms had been present for only a few months. In all but one case, resuscitation with the artificial kidney was necessary before transplantation could be considered; the greatest number of preoperative hemodialyses was 35 (patient LD 1). 


\section{Donor Selection}

All 22 patients received kidneys from living volunteer donors. For reasons discussed below, familial donors were considered to be the most suitable, particularly at the time of treatment of the first 16 patients when histocompatibility matching was not being done. Principally because of the young age of the recipients, most of the kidneys (18 in all) were obtained from parents. One each was from a sister, aunt or uncle. Two homografts were from nonrelatives (Table 9). Two homografts were used in case LD 19. The first one, obtained from the mother, failed acutely, presumably because of a donor-recipient blood group incompatibility, and was removed immediately. A second kidney from an unrelated donor was placed two weeks later; in the summary statistics only the second or definitive donor is considered further.

The role of donor and recipient blood groups in determining the advisability of transplantation is an important one. It is now recognized ${ }^{20,49,52}$ that tissue transfer between donors and recipients of different blood types should conform to the general rules which apply for unmatched blood transfusions (Table 10). Early in our experience this scheme was violated on four occasions, including two of the pediatric cases in the present report. Two homografts of A and B type respectively failed immediately in $\mathrm{O}$ recipients, apparently owing to binding of host isoagglutinins to the red cell antigens which are known to be present in renal tissue. ${ }^{10,18,63}$ In a third case (A to O) the homograft functioned well (Fig. 23) for 202 days, until the recipient's death from nonrenal causes (LD 20, Table 9). A fourth patient, an adult of A blood group who received a kidney from his B type sister, is in good health more than $2 \frac{1}{2}$ years after operation with excellent renal function. Thus the principal risk with the use of the unacceptable donor-recipient blood type incompatibilities seems to be an acute one due to an immunologic reaction that may be distinct from that of rejection. Although such tissue combinations should not be used in the future because of the danger of immediate failure, it is pertinent in considering the role of red cell antigens in rejection that long-term function has been obtained in the foregoing two cases and in a third patient reported by Lawrence. ${ }^{25}$

Having determined the blood type suitability of a willing donor, a thorough general medical examination is conducted, as well as detailed renal function tests, multiple urine cultures, and an intravenous pyelogram. If the prospective donor proves to be absolutely normal, a retrograde aortogram is obtained. A kidney with a double arterial supply is not removed. Although it is not difficult to revascularize such organs, the necessary ischemia times have been longer in our hands, a factor which has a proved adverse effect upon early function. ${ }^{49}$ The consequent extra risk of failure is not thought to be justified if a living donor is involved.

\section{Histocompatibility Tests}

One of the most pressing needs in the field of clinical homotransplantation is the development of accurate and practical methods for preoperative detection of histocompatibility, since the vigor and perseverance of the subsequent rejection are related to the degree of genetic dissimilarity between the donor and recipient. ${ }^{46,48}$ It is undoubtedly for this reason that the best results in our total experience in all age groups ${ }^{61}$ and in the 
collected world statistics ${ }^{39}$ have been with the use of familial donors; here the mathematical possibility of fortuitous histocompatibility matching is increased..$^{47}$ Nevertheless crushing rejection has been encountered after intrafamilial homotransplantation, emphasizing that not all related donors are suitable. Conversely, smooth and uninterrupted recovery has been observed in some patients after homotransplantation of nonrelated kidneys. It is evident that there is a spectrum of donor suitability for the individual recipient in both the related and nonrelated populations. Eventually, it is to be hoped that the favorable and unfavorable donors can be distinguished with the antigen matching methods now being developed in a number of laboratories. Progress in this field was recently summarized in the proceedings of a National Academy of Science Seminar held in June, 1964. ${ }^{17}$

Until now the development of tissue matching techniques has been hampered in man by the absence of knowledge about the number, location and strength of human histocompatibility antigens. Terasaki, at the University of California in Los Angeles, has attempted to obtain this kind of information by retrospective study of chronically surviving recipients and their donors from the Denver, ${ }^{61}$ Boston $^{66}$ and UCLA series. His method involves the use of a panel of different cytotoxic antiserums obtained from presensitized plasma donors ${ }^{61}$ which differentially destroy tested lymphocytes according to their antigen content. In his initial studies Terasaki found the correlation between the clinical course and the donor-recipient antigen matches to be irregular and incomplete. Nevertheless the best results tended to be in those patients who had the greatest antigen similarity to their donors. ${ }^{61}$

Because of these suggestive findings, a prospective study was undertaken in October, 1964, in which all donors for new cases were selected partly upon the basis of their antigen match with the recipient. Included were the last six patients in the presently reported series. Since the institution of this screening program, uncontrollable rejection has not been observed, but the length of follow up is still too short to permit the conclusion that the method is of value. All six pediatric patients with Terasaki selected donors are still alive, from $3 \frac{1}{2}$ to nine months post-operatively.

\section{The Ethical Issues}

The ethical and social problems accompanying clinical research in the field of homotransplantation have been the subject of editorial comment by Elkinton, ${ }^{8}$ Robin ${ }^{45}$ and other prominent members of the scientific community. At the time the opinions of most of these authors were expressed, it was not generally known that the results after clinical homotransplantation had already undergone a remarkable improvement. It was, therefore, reasonable to question the propriety of applying a form of therapy which seemed foredoomed to early failure. Unfortunately, the recognition that transplantation can offer significant prolongation of life to the uremic patient has not eliminated the moral issues which must be faced today, particularly in formulating policy for treatment of pediatric patients.

As discussed above, the use of living donors increases the chance of success, since optimally preserved tissue can be ensured under controlled circumstances. Moreover, the use of kidneys from blood relatives improves the outlook, since the probability is greater of obtaining a good donor-recipient histocompatibility match. Thus the best donor, short of an 
identical twin, is most likely to be a parent or a sibling who has reached the age permitting legal consent (21 years). Performance of homotransplantation under these circumstances provides the best prognosis for the recipient. It also carries a medical risk, however small, for the donor, and it introduces the possibility that a donor may be selected on the basis of presumed expendability by familial arbitration and coercion. Transplantation under less optimum conditions, such as with the use of unrelated volunteer donors, reduces the chance of recipient survival. ${ }^{89,49}$ Traditional morality would seem to be best served with the use of cadaveric organs, if one excludes from consideration the prospective recipient whose chances of living are thereby further reduced. Even the use of cadaveric organs is not free of onus; the right of a dying prospective cadaveric donor to receive the full measure of available therapy must be protected without regard for the events that are expected to follow after death.

These and other matters have, of course, occupied the attention of all groups working in this field. Before undertaking the care of children or infants, additional factors must be considered as described by Riley. ${ }^{44}$ These include preoperative evaluation of the effect of such an undertaking on family unity, and upon the mental health of siblings. Perhaps the greatest doubt of all is posed by the fact that the ultimate prognosis is not yet known in that group of survivors now living, in apparent good health, $1 \frac{1}{2}$ to three years after operation. If their homografts gradually fail during the next five or 10 years, will the benefits be comparable to those in the vocationally trained adult for whom such an interim of borrowed time could mean a return to work and pre-existing social responsibility? Woodruff ${ }^{69}$ has reminded us that it is not our task to confer immortality. One might also wonder whether any man has the wisdom to adjudicate the relative value of another's years, even those of a child.

\section{Preservation of Tissue}

Whether the homograft is from a living donor or from a cadaver, it is subjected to a variable period of ischemia. The easiest means of minimizing the anoxic injury is organ cooling. Kidneys obtained from volunteer donors are perfused immediately after removal with cold lactated Ringer's solution containing $50 \mathrm{mg}$. of heparin and $1 \mathrm{Gm}$. of procaine chloride per liter (Fig. 24). In dogs this simple expedient provides good protection of the autografted kidney during devascularization for one or more hours. The duration of permissible total ischemia for the homograft is probably not as long as this for reasons discussed elsewhere. ${ }^{49}$ From practical experience it has been learned that prompt renal function of the human homograft can be expected if the kidney is cooled by this method and revascularized in the host within 40 minutes. ${ }^{49}$ Urine excretion may occur after much longer periods of ischemia, but reliability of early function is progressively reduced with greater intervals of tissue anoxia.

Cooling of the postmortem homograft is also of paramount importance. Using various methods of cold perfusion or simple cooling, Dunea, ${ }^{6}$ MacLean, ${ }^{26}$ Hume,${ }^{20}$ Hamburger ${ }^{13}$ and Mowbray ${ }^{38}$ have all recently had improved results with cadaveric kidneys. Although prompt renal function was often not obtained as the consequence of acute tubular necrosis, skillful post-transplant dialysis care was used to maintain the recipient patients until the ischemic injury had healed. It is probable that the ideal candidate for cadaveric 
transplantation is a patient who has already entered and been stabilized on a chronic dialysis program. If the cadaveric kidney does not function properly at first, the previous care with the artificial kidney can be continued for some days or even weeks until the damaged organ begins to excrete adequate quantities of urine. As discussed below, special precautions with immunosuppressive drugs are necessary in such patients with delayed or poor initial function.

The methods of cooling, though valuable, allow only short term preservation. In the future, perfusion techniques will probably be developed which will permit storage for much longer periods of time. The value of hypothermia in combination with extracorporeal whole or partial cadaver perfusion has already been demonstrated, ${ }^{30,32}$ using a commercial heart-lung apparatus to provide an artificial postmortem circulation. Perfusion of single organs is more difficult, ${ }^{4}$ but if such methods become practical, they will make possible the establishment of banks for which vital organs could be removed from cadavers, have their function evaluated in the extracorporeal state, and be used for elective operations.

\section{Technical Problems}

Detailed descriptions of the donor operation are available. ${ }^{27,49}$ To date there have been no reported deaths in living volunteers. The high degree of safety with which nephrectomy can be carried out is probably ascribable to two factors. First, the removal of a normal kidney is not ordinarily difficult. Second, these operations have been performed with ideal exposure and with unusually great care. None of the living donors at the University of Colorado Medical Center has required blood transfusion.

All the 22 recipient patients in the present series also had removal of their spleen and diseased kidneys. The splenectomy and nephrectomies were performed at the same time as the transplantation, except in two cases.

Special problems may be encountered in homotransplantation to recipients of young age if adult kidneys are used. For almost all children 12 years or older, the standard extraperitoneal operation of Küss ${ }^{24,40}$ is satisfactory. After removal, the kidney is usually placed in the opposite iliac fossa of the recipient, thereby reversing the normal anteroposterior relations of the hilar structures (Fig. 25). In its new position the pelvis and ureter are anterior, the renal artery is intermediate, and the renal vein posterior. The renal artery is attached to the hypogastric artery and the renal vein to the side of the external iliac vein. The ureter is implanted directly into the bladder by a nipple and tunnel technique (Fig. 25), or attached with an end-to-end anastomosis to the distal portion of the recipient ureter; alternatively, ureteropelvic anastomosis may be used. The preoperatively placed Foley catheter is removed in 24 hours. Internal splints or catheters are not used.

In children under 12 in whom the iliac fossa may be too small for accommodation of an adult kidney, a transperitoneal operation is advisable ${ }^{55}$ through a total midline incision (Fig. 26 , insert). The right colon is reflected to the left, and the renal vessels are anastomosed endto-side to the aorta or vena cava or to the common iliac vessels (Fig. 26). Six of the 22 children in the present series had this operation. There were no technical failures. Because of the small size of the recipient, the length of homograft ureter necessary to reach the bladder 
or to reach the distal portion of the recipient ureter is not increased. Since the vascular anastomoses are made as large as will ever be required, there should be no problem of late anastomotic stenosis due to recipient growth.

Adult homografts have been used in recipients as young as three years. There have seemed to be no physiologic problems with the use of such a disproportionately large organ homograft. Heart failure was not observed. One of the children had intestinal obstruction from an adhesive band at the site of the right colonic reflection, which was easily treated at a secondary operation. Four of the six children operated upon with this technique are still alive after $3 \frac{1}{2}$ to $25 \frac{1}{2}$ months.

\section{General Postoperative Care}

If a well functioning homograft is placed, the problems of fluid and electrolyte management may be exaggerated in the infant or young child. Massive diureses have been observed of as much as $2000 \mathrm{ml}$. per hour. The electrolyte composition of the urine at this time is usually about $100 \mathrm{mEq}$. of sodium, $70 \mathrm{mEq}$. of chloride and $15 \mathrm{mEq}$. of potassium. ${ }^{58}$ Serious errors of fluid therapy can be introduced, however, unless repeated plasma and urine electrolyte determinations are carried out. One of the deaths in the present series (LD 26) occurred as a result of an acute electrolyte disorder during the first postoperative day. Iatrogenically induced hyponatremia and hyperkalemia were followed by cardiac arrest.

The acute post transplant diuresis usually runs its course within 24 to 48 hours. During this time one patient (LD 17) lost more than 30 pounds. A remarkable improvement in their general medical condition occurs during this time. The patients usually have a much more rapid early convalescence than their donors. Unless contraindicated, diet is resumed on the morning after operation and ambulation started that evening.

\section{Immunosuppression}

Although the above described technical and general medical details of care are of the utmost importance, the unique problem of transplantation surgery is the prevention of homograft repudiation by the host. If aggressive measures are not taken, the good early function which follows operation ceases within a few days or weeks in all but the exceptional case. Since there is at present no highly specific form of therapy, consistent success depends upon the combined use of several therapeutic adjuncts. These include the drugs azathioprine, actinomycin $\mathrm{C}$ and prednisone. Local homograft irradiation or total body irradiation has also had wide clinical use.

In most centers the most useful pharmacologic agent has been azathioprine, ${ }^{*}$ a cytotoxic drug which interferes with nucleic acid synthesis. ${ }^{2,8}$ Therapy is started at the time of or frequently several days in advance of homotransplantation. In all cases it has been continued indefinitely thereafter. An immunosuppressive effect is observed without suppression of the white cell count to dangerous levels, and, indeed, the accidental production of leukopenia has been the most common cause of early failure. The appropriate daily dose of the drug is

\footnotetext{
*Imuran, Burroughs Wellcome \& Co., Inc., 1 Scarsdale Road, Tuckahoe, New York
} 
variable, ranging from 1 to $6 \mathrm{mg}$. per kilogram, and is adjusted according to the white blood cell counts. Since azathioprine has a partial renal pathway of detoxification, ${ }^{7}$ the dose should be reduced in the event of the secondary renal failure which may accompany a severe rejection episode. Similarly, if a kidney is transplanted which fails to function properly at the outset, as is often the case with cadaveric homografts, doses should be prescribed which are considerably smaller than in the usual case.

In spite of its usefulness in clinical homotransplantation, azathioprine alone does not usually prevent an acute rejection episode. In our earlier experience in which pharmacologic agents were added serially to the therapeutic regimen, only two of 45 patients escaped rejection. In this series the use of prednisone in large doses added at the time of acute postoperative homograft failure seemed to be lifesaving (Fig. 27). Because of this almost invariable sequence of events and because it was later observed ${ }^{49}$ that prophylactic steroids in large doses often reduced the severity or even prevented early rejection, we now use prednisone from the time of operation, usually in doses of 0,5 to $1 \mathrm{mg}$. per kilogram, until the onset of clinical rejection. At that time the dose is increased to 2 to $8 \mathrm{mg}$. per kilogram.

Two other adjuncts are of value at the peak of a rejection crisis. Actinomycin C, which was demonstrated by Calne and his associates ${ }^{2}$ to cause reversal of rejection in animals, is given every four or five days in doses of 200 to 400 micrograms (Fig. 29). Local homograft irradiation is administered in three doses as described by Kauffmann, ${ }^{22}$ using $150 \mathrm{R}$ at depth on each occasion.

The use of total body irradiation in American clinics has been largely abandoned because of the high mortality rate from complications, particularly sepsis. Hamburger ${ }^{14,15}$ in Paris has, however, continued to use total body ionizing irradiation with excellent results. Only one patient in the Colorado series received total body irradiation (LD 1). His white cell count was depressed to approximately 500 for almost two weeks after operation, and after recovery from this episode he was converted to Imuran and steroid therapy (Fig. 28).

\section{Clinical Features of Rejection in Patients Receiving Immunosuppression}

The diagnosis of post-transplant rejection depends upon multiple clinical observations. ${ }^{41,} 49$ Its features are most easily recognized in patients who have had good initial homograft function and are receiving treatment with azathioprine alone. Under such circumstances a secondary decline of renal excretion is almost certain evidence of rejection, particularly if a systemic febrile illness is present concomitantly. A classic example is shown in Figure 27. The patient, who received a kidney from her mother, had excellent function for the first postoperative week. At that time there was a decline in creatinine clearance, a secondary rise in blood urea nitrogen level, proteinuria, a tendency to hypertension, and fluid retention. She complained of tenderness over the transplant wound and had a fever in excess of $39^{\circ} \mathrm{C}$. The addition of large doses of prednisone and intermittent intravenous administration of actinomycin $\mathrm{C}$ to the basic therapy with azathioprine resulted in reversal of these findings. If prompt improvement is not noted in such cases, local homograft irradiation is applied immediately. 
Although the reversal of rejection is a phenomenon of great importance in making clinical transplantation a practical undertaking, an additional feature is equally noteworthy. After reversal has been accomplished, the intensity of immunosuppressive therapy is ordinarily less than that required for control of the initial crisis. It is improbable that many patients could live for protracted periods of time if the aggressive therapy required early had to be extended into the later course. In actuality, it is usually possible to begin withdrawal of steroids within the next few days or weeks. The patient illustrated in Figure 27 had steroids discontinued altogether after one year. During the subsequent year she has received only azathioprine, the drug which initially did not prevent the onset of a relatively severe rejection. Her homograft biopsy 23 months after operation was normal except for a small amount of subcapsular scarring.

\section{Late Rejection}

Although there is an increased element of security with the passage of time, the threat of late rejection months or even years after homotransplantation is a significant one. ${ }^{14,15,57,61} \mathrm{In}$ the total series of Colorado cases, including adults, 12 examples of delayed rejection have been observed, three in the pediatric series herein reported (LD 13, 22, 41). Invariably, these have seemed to be precipitated by the withdrawal or reduction in dose of prednisone (Fig. 29). Although this complication was partially reversible, there was some permanent loss of renal function in most instances. The discontinuance of prednisone or even its reduction to doses below 0.5 to $1 \mathrm{mg}$. per kilogram must therefore be done with caution and with careful weekly re-evaluation of renal function. The most useful indicator of late rejection has been the creatinine clearance, which may slowly decline for some days or weeks before elevations in blood urea nitrogen are observed. When late rejection is diagnosed the only effective form of therapy is intensification of the immunosuppressive regimen, the most important step being to increase the prednisone dose.

\section{Causes of Death}

One of the four unsuccessfully treated patients (LD 26) in the present series died of acute electrolyte imbalance during the postoperative diuresis. Another (LD 20) succumbed after 202 days (Fig. 23) of a central nervous system disorder of unknown origin. Renal function was adequate. Permission for autopsy was denied. The other two patients (LD 19, 61) died at 95 and 36 days of Pneumocystis carinii pneumonitis (Fig. 30) and E. coli septicemia, respectively; the longer survivor had satisfactory renal function (Fig. 31), but the other child was at the peak of a rejection episode. The contribution of immunosuppressive therapy to deaths such as the latter two has been discussed in detail elsewhere. ${ }^{49}$

\section{Late Azathioprine Toxicity}

Although sepsis during the use of maximal immunosuppressive therapy is the most common fatal complication early after homotransplantation, patients who survive beyond the first few months have surprisingly little susceptibility to significant infection. Reactivity to various test antigens is reduced. ${ }^{23,} 68$ Nevertheless none of the 18 surviving pediatric patients has been troubled with recurrent late infection. 
To date the principal late problem with azathioprine has been hepatotoxicity. In dogs this drug has been shown to be a significant liver poison which causes hepatic injury within a few days after beginning administration. ${ }^{58}$ The high degree of toxicity is apparently speciesspecific for the dog, but four adults in our experience have suffered severe liver injury after months or years of azathioprine therapy; one of these patients died of a combination of liver failure and bacterial sepsis. ${ }^{61}$ Thus far this has not been observed in patients of 18 years or less. Nevertheless periodic liver chemistry studies should be obtained on all patients receiving this agent.

\section{Problems Peculiar to the Pediatric Patient}

Although the young victims of terminal renal disease have proved to be exceptionally favorable candidates for homotransplantation, they have presented unique problems in care. The technical difficulties and the complexities of early fluid and electrolyte management have already been mentioned. An additional feature which deserves special emphasis is the postoperative tendency of the young patient to bizarre peripheral blood patterns, particularly normoblastemia. An example is shown in Figure 23 of a five-year-old boy whose nucleated peripheral blood cell count of almost 50,000 consisted of 40,000 normoblasts. Failure to recognize the significance of this peculiar differential could lead to the administration of excessive azathioprine doses. An association of this finding with polycythemia has been described by Nies. ${ }^{42}$

Therapy with prednisone is also a matter of increased concern in the growing child. The resultant acne, weight redistribution, cosmetic facial deformity and rapid weight gain may cause an exaggerated psychologic reaction. In addition, three of the patients in the present series suffered unilateral or bilateral spontaneous fractures of the femoral head, also apparently as the consequence of steroid therapy.

Finally, the most alarming consequence of steroid administration has been retardation of body growth in those unfortunate patients who require this agent chronically in order to maintain homograft function. The dilemma is illustrated in Figure 32. The children on the left and right had prednisone discontinued after five months and one year respectively, with rapid subsequent growth. The five-year-old boy in the middle had both early and late rejection episodes and is still receiving $7.5 \mathrm{mg}$. per day. His height has remained almost unchanged during the two years since transplantation. It is possible that he will ultimately be a dwarf, with a well functioning kidney.

\section{Splenectomy and Thymectomy}

As reported earlier, all patients in the present study had splenectomy, and six have had thymectomy either prior to transplantation or subsequently. ${ }^{49,60,61}$ The rationale for and the evidence concerning the benefit of these adjuvant procedures have been considered at length in the cited publications. At the moment it is not clear whether either additional procedure is of value in modifying rejection, although there is suggestive evidence that thymectomy may ultimately prove to be useful. ${ }^{21,33,34,61}$ 


\section{Survival, Renal Function and Rehabilitation}

Because of the differences in duration of follow-up, the cases have been classified as group I and group II. Those in group I were all treated more than a year and a half ago. Twelve (75 per cent) of these 16 patients are still alive after 21 to 36 months (Table 11). All have good renal function. Three have had steroid therapy discontinued. Only three patients are currently receiving as much as $10 \mathrm{mg}$. of prednisone per day (Table 9). In each case function has been stable for at least one year. Five of the 12 patients still receive some antihypertensive medication for control of blood pressure. The current renal function, steroid dose, blood pressure, and need for antihypertensive drugs are listed for each case in Table 9.

The six patients in group II were operated on from $3 \frac{1}{2}$ nine months ago. All are still alive with adequate renal function. Similar data are given for each of these cases in Table 9. Social rehabilitation has been relatively complete in both groups.

\section{Pathologic Studies}

The changes in renal homotransplants early after operation have been extensively described. ${ }^{43,49}$ Of greater interest is the appearance of the chronically tolerated kidney. Eight of the patients in the presently reported series have received biopsies of their homografts from 21 to 26 months after operation. Only one of the biopsies (LD 33) was within normal limits. Seven of the other specimens showed vascular lesions and cellular infiltration; two in addition showed thickening of the glomerular capillary basement membranes.

In all the kidneys with vessel changes the interlobular arteries were narrowed by fibrous intimal thickening (Fig. 33), a process which had gone on to complete obliteration of the lumen in several instances. The most severe lesions were present in two cases (LD 22, 41) which had experienced a second phase of late rejection. At present it seems probable that these obliterative vascular lesions are the legacy of such past episodes of acute homograft reaction. Tubular atrophy and interstitial fibrosis were present in all the cases with occlusive vascular lesions (Fig. 34); secondary hypertension had occurred in several of these patients.

In the two renal homografts with glomerular deposits (LD 1,41) material staining positively with periodic-acid-Schiff reagent was present on the tuft capillary basement membranes and between the endothelial cells, giving an appearance closely resembling that seen in Ellis type 2 glomerulonephritis (diffuse membranous glomerulonephritis) (Fig. 35). There is evidence that this coating substance is gamma globulin, and it may represent deposits of antigen-antibody complexes.

Many of the host cells infiltrating the interstitium were large lymphocytes having a prominent Golgi apparatus and pyroninophilic cytoplasm containing many free ribosomes (Fig. 36). Probably these cells are producing antibody against the graft and are evidence of a continuing low-grade immunologic attack by the host even between the acute episodes recognized clinically as rejection. The number of small lymphocytes and plasma cells in the interstitial infiltrate varied. Macrophages and fibroblasts were also present. 
Hyperplasia of the juxtaglomerular apparatus was present in six of the eight transplants (LD 13, 17, 22, 33, 34, 41) (Fig. 37). It was not necessarily associated with arterial narrowing or hypertension. Since a similar change is found in renal autografts and isografts, it is possibly concerned with the maintenance of normal production of renin and perhaps erythropoietin.

A summary of pathologic findings in these eight kidneys is recorded in Table 12.

\section{Liver Transplantation}

In view of the encouraging results after renal homotransplantation, it has been natural to think of extending comparable replacement therapy to diseases which result in functional failure of other organs. At present, liver transplantation appears to offer the most immediate possibility of clinical utility.

\section{Orthotopic Liver Transplantation}

Such hope derives principally from studies in dogs. The most incisive experiments have involved orthotopic transplantation in which the recipient animal's own liver is excised and replaced with a homograft obtained from an unrelated mongrel animal ${ }^{31,35,36,37,50,51,58}$ with a technique similar to that depicted in Figure 38. With this preparation there is no equivocation about the presence or absence of transplant viability, since survival provides incontrovertible proof of continuous homograft function.

The immediate operative mortality rate of orthotopic liver transplantation in the dog is 10 per cent or less, and the incidence of long-term success is comparable to that attainable after homotransplantation of the dog kidney. ${ }^{58}$ With both organs the severity of the subsequent rejection is highly variable in individual experiments, a finding undoubtedly explained by differences in the quality of chance histocompatibility matching as discussed earlier. In a recently reported series of nearly a hundred canine liver homotransplantations in which azathioprine alone was given for immunosuppression, approximately 20 per cent of the recipient animals had no clinical evidence of rejection (Fig. 39); the histologic injury to these homografts was minimal. At the other end of the spectrum, about one third of the dogs had some delay in the onset of rejection, but death due to homograft malfunction occurred after one to six weeks. Finally, half of the dogs had varying manifestations of early rejection, but with eventual partial or even relatively complete reversal of the consequent biochemical abnormalities (Fig. 40); in these animals immunosuppressive therapy was not intensified during the rejection episode. This consistent finding emphasizes the important principle that immunologic rejection tends to be spontaneously remittent.

Recently the effects of reversible rejection upon late hepatic function and structure have been extensively analyzed. ${ }^{58}$ It seems probable that all homografts, even those in which function is not demonstrably impaired, undergo early invasion by pyroninophilic mononuclear cells, the maximum infiltration usually being between the first and third weeks. After this time the predominant histologic features in most homografts were those of repair and regeneration, with either absent or relatively minor degrees of continuing destruction. Since the main rejection damage was centrizonal, the healing was most prominent in these areas with interconnecting fibrosis around the central veins, centrilobular 
bile canalicular dilatation and cholestasis, and pseudolobule formation. In some of the homografts, increased connective tissue was also present in the portal tracts (Fig. 41, upper), but in others, including the longest survivor, there were no residual abnormalities whatever (Fig. 41, lower).

As after human renal transplantation, the need for immunosuppressive therapy has seemed to be diminished in dogs with chronically functioning orthotopic liver homografts. The four longest surviving dogs in our laboratory after hepatic transplantation had azathioprine discontinued after 17 weeks and are still alive, now 12 to 20 months post-operatively (Fig. 42). In five other dogs, however, cessation of therapy was followed by indolent and progressive late rejection which either led to death or necessitated resumption of daily administration of azathioprine.

Despite the demonstration that orthotopic transplantation does not present insurmountable problems, this method has not been successfully applied for the treatment of patients. To date seven attempts have been made at human orthotopic transplantation, five in Denver, ${ }^{59,} 62$ one in Boston ${ }^{35}$ and one in Paris. ${ }^{5}$ Six of these patients had primary malignancy or metastasis in their own livers, and the seventh was a child with biliary atresia; two died during or immediately after operation. The other five lived for six, seven, 12, 22 and 23 days. Experience with these cases has delineated certain specific problems which will have to be dealt with in future trials.

First, the degree of anoxic injury to the cadaveric livers used was moderately severe in all instances, evidenced by abrupt increases in SGOT and SGPT and bilirubin immediately or early after operation. Fortunately, this acute anoxic injury proved to be reversible in all but one of the Colorado cases, but the less than ideal circumstances of tissue procurement and preservation will continue to be a serious handicap,

Secondly, the technical problems with orthotopic transplantation in the human patient exceed those of most other kinds of surgery. The presence of widespread hepatic malignancy (Fig. 43) makes removal of the bulky livers difficult. Moreover, most such patients have portal hypertension. In addition, the need for multiple vascular anastomosis (Fig. 38) and for establishment of internal biliary drainage further compounds the risk.

Finally, changes in. the coagulation mechanism have proved to be of the utmost importance. Most patients with terminal liver disease enter surgery with impaired clotting. During manipulation of the liver and especially during the anhepatic phase of the actual transplantation, acute fibrinolysis is characteristic. ${ }^{65}$ In order to prevent bleeding at this critical time, the first four patients in the Denver series were given epsilon aminocaproic acid (EACA), human fibrinogen and fresh blood.

Ironically, the early threat of fatal hemorrhage is succeeded after successful orthotopic transplantation by a period of hypercoagulability beginning within a few hours after operation. ${ }^{65}$ Three of our patients had peripheral venous thrombosis, apparently at this phase of convalescence, ${ }^{56,59,62}$ with the subsequent development of multiple pulmonary emboli. Evidently a natural rebound hypercoagulability was exaggerated in these cases by the clot- 
promoting agents administered during operation. In future trials iatrogenic manipulation of the coagulation process seems contraindicated.

Pathologic studies of the homografts from these unsuccessfully treated patients have not diminished the hope that such operations may ultimately prove to be feasible. In the Denver series the four patients who survived operation and received the same general immunosuppressive regimen used for kidneys all had relatively good preservation of liver architecture (Fig. 44). Mononuclear cell invasion was relatively minimal, and the degree of hepatocyte loss and reticulin condensation seemed less than in animals at a comparable stage of convalescence. ${ }^{56,59}$ Death resulted from factors other than crushing rejection, as discussed in detail elsewhere. ${ }^{56}$

\section{Auxiliary Liver Transplantation}

At first thought auxiliary hepatic transplantation, in which the patient's residual liver tissue is not removed, would seem to have important advantages for the treatment of benign diseases such as congenital biliary atresia or Laennec's cirrhosis. With these techniques, first described by Welch, ${ }^{11,67}$ the homograft is placed in a heterotopic position such as the pelvis (Fig. 45, A) or left upper portion of the abdomen. It has recently been demonstrated that the method of venous revascularization of such a homograft is of paramount importance in determining its subsequent fate, at least in animals.

With Welch's preparation, in which the pelvic homograft received its venous inflow from the terminal inferior vena cava, a remarkable atrophy of the auxiliary liver was noted in dogs treated with azathioprine, usually beginning within two weeks. ${ }^{54,60}$ Subsequent studies have explained this phenomenon. ${ }^{28,} 29$ If the portal supply of the extra liver was derived from the splanchnic venous system (Fig. 45, B), the homografted liver did not atrophy, and instead there was symmetrical shrinkage of the host liver. These findings indicate that there can be a competitive relation between coexistent livers. In dogs the organ which is perfused with venous return from the splanchnic bed operates at a physiologic advantage. If neither liver is provided with direct splanchnic venous blood flow, as illustrated in Figure 46, the hepatic tissue which receives the greatest total blood is favored, but the degree of preservation is less complete than with ideal vascularization. ${ }^{12,64}$

In the human patient with terminal benign liver disease, the role of the foregoing factor of substrate competition is not known. The diseased liver in such patients has lost much of its capacity for competition, and, in addition, the portal contribution to total hepatic flow is apt to be greatly reduced. For these reasons and because provision of splanchnic flow for the auxiliary homograft is mechanically difficult, two patients treated in Denver received the compromise procedure depicted in Figure 46. Preliminary portacaval anastomoses were performed four days and one day before the transplantation, respectively. Laennec's cirrhosis was the underlying disease.

In both cases the auxiliary livers functioned immediately, but the improvement in liver chemistries secondarily deteriorated from seven to 10 days later (Figs. 47, 48), The patients died of septic complications at 22 and 34 days, before there was evidence of reversal of the clinically diagnosed rejections. The first patient had staphylococcal pneumonia, and the 
second had Pneumocystis carinii, cytomegalic virus inclusion disease and hemorrhagic monilial enterocolitis.

Pathologic studies of these two auxiliary homografts produced evidence of active rejection in the patient who survived for 22 days. The portal tracts were infiltrated with mononuclear cells, between 5 and 10 per cent of which were large lymphocytes with pyroninophilic cytoplasm (Fig. 49). There were also foci of fibrinoid necrosis in the walls of several of the smaller branches of the hepatic artery. Absence of infiltrating cells and lack of vascular damage made it difficult to believe that acute rejection was occurring terminally in the second, longer-lived hepatic homograft. This liver at 34 days did, however, show necrosis of the centrilobular hepatocytes, accompanied by collapse and condensation of the centrizonal reticulin (Fig. 50). Cytomegalic virus inclusions were present in the biliary epithelial cells (Fig. 51). It is tempting to think that this centrizonal damage had occurred at the time of rejection and was in the process of being repaired when the patient died from infection by opportunistic organisms. Centrilobular cholestasis with bile "thrombi" was a prominent feature of both hepatic homografts.

In a third case an attempt at auxiliary homotransplantation to a 15-month-old child with biliary atresia failed immediately because of technical complications. Other trials have been made by Absolon, ${ }^{1}$ Hermann, ${ }^{16}$ Hume ${ }^{19}$ and Gliedman, ${ }^{9}$ all resulting in early death. In several of these cases, difficulty was encountered in closing the abdomen, owing to the mass of the extra organ. Predictions about the future usefulness of the auxiliary operations should be held in abeyance for the moment in view of these mechanical problems, because of the unknown influence of the physiologic factors alluded to above, and because animal results with auxiliary transplantation have not been as promising as with the orthotopic operation.

\section{Summary}

Experience has been recounted with 22 patients treated with renal homotransplantation at or before the age of 18 years. Eighteen of the 22 patients are still alive from $3 \frac{1}{2}$ months to three years after operation. Twelve are alive at least 21 months postoperatively; eight of the 12 are two to three years. The unique technical, medical and sociologic problems encountered in treating patients of this age group are described. Biopsies of eight of the homografts from 21 to 26 months after operation revealed that only one of the kidneys was normal. The others showed narrowing of the interlobular arteries by fibrous intimal thickening and interstitial infiltration by large lymphoid cells. In two of the homografts there was also thickening of the glomerular capillary basement membranes, giving an appearance resembling diffuse membranous glomerulonephritis. Juxtaglomerular hyperplasia was present in six of the eight homografts.

Progress in the field of liver transplantation is also cited. The principal encouraging developments have been in animal experimentation. Although long-term survival in human subjects has not yet been achieved, dogs with orthotopic liver transplantation have been living in good health for as long as 20 months. Advances have also been made bearing upon auxiliary liver transplantation, an operation which does not involve removal of the patient's own liver. Although preservation of the patient's liver would seem to be advantageous for 
several reasons, there are also serious and fundamental disadvantages to this approach which may limit its usefulness.

\section{Addendum}

Since submission of this manuscript, two additional patients with renal homotransplantation have died. The first patient (LD 79), who had poor function at the time of the original report, died of a fungal sepsis of the brain and lungs (Aspergillus fumigatus). There was extensive histologic injury to the homograft. Survival was 254 days.

The second patient (LD 80) died of systemic histoplasmosis. There was almost no evidence of rejection injury to his kidney. Survival was 295 days.

\section{Acknowledgments}

Aided by grants AM 06283, AM 06344, HE 07735, AM 077772, AI 04152, FR 00051 and FR 00069 from the United States Public Health Service and by a grant from the Medical Research Council of Great Britain.

\section{References}

1. Absolon, KB. Personal communication.

2. Cake RY, Alexandre GPJ, Murray JE. A Study of the Effects of Drugs in Prolonging Survival of Homologous Renal Transplants in Dogs. Ann New York Acad Sc. 1962; 99:743. [PubMed: 14017936]

3. Calne RY, Murray JE. Inhibition of the Rejection of Renal Homografts in Dogs by Burroughs Wellcome 57-322. Surg Forum. 1961; 12:118. [PubMed: 13875839]

4. Couch NP, Cassie GF, Murray JE. Survival of the Excised Dog Kidney Perfused in a Pump Oxygenator System. I. Circulatory Changes in the Hypothermic Preparation. Surgery. 1958; 44:666. [PubMed: 13592615]

5. Demirleau J, et al. Tentative d'homogreffe hepatique. Memoires de l'academie de Chirurgie (Paris). Feb 5.1964

6. Dunea G, et al. Renal Homotransplantation in 24 Patients. Brit M J. 1965; 1:7. [PubMed: 14213121]

7. Elion GB, Callahan S, Bieber S, Hitchings GH, Rundles RW. A Summary of Investigations with 6[(Methyl-4-nitro-5-imidazolyl) thio] Purine (B.W. 57-322). Cancer Chemotherapy Reports (No 14). Oct.1961:93.

8. Elkinton JR. Moral Problems in the Use of Borrowed Organs, Artificial and Transplanted. Ann Int Med. 1964; 60:309. [PubMed: 14114451]

9. Gliedman, ML. Personal communication.

10. Glynn LE, Holbrown EJ. Distribution of Blood Group Substances in Human Tissue. Brit M Bull. $1959 ; 15: 151$.

11. Goodrich EO, Welch HF, Nelson JA, Beecher TA, Welch CS. Homotransplantation of the Canine Liver. Surgery. 1956; 39:244. [PubMed: 13298971]

12. Halgrimson, CG. Personal communication.

13. Hamburger, J. Personal communication.

14. Hamburger J, Crosnier J, Dormont J. Experience with 45 Renal Homotransplants in Man. Lancet. 1965; 1:985. [PubMed: 14289847]

15. Idem. Observations in Patients with a Well-Tolerated Homotransplanted Kidney: Possibility of a New Secondary Disease. Ann New York Acad Sc. 1964; 120:558. [PubMed: 14235274]

16. Hermann, RE. Personal communication.

17. Histocompatibility Testing. National Academy of Science-National Research Council; Washington, D. C.: 1965. 
18. Hogman CF. Blood Group Antigens A and B Determined by Means of Mixed Agglutination on Cultured Cells of Human Fetal Kidney, Liver, Spleen, Lung, Heart and Skin. Vox Sang. 1959; 4:12. [PubMed: 13648264]

19. Hume, DM. Personal communication.

20. Hume DM, et al. Studies of Renal Homotransplantation in Man. Ann New York Acad Sc. 1964; 120:578. [PubMed: 14235275]

21. Jeejeebhoy HF, Lond MB. Effects of Rabbit Anti-rat-Lymphocyte Plasma on Immune Response of Rats Thymectomized in Adult Life. Lancet. 1965; 2:106. [PubMed: 14330031]

22. Kauffman HM Jr, Cleveland RJ, Dwyer JJ, Lee HM, Hume DM. Prolongation of Renal Homograft Function by Local Graft Radiation. Surg, Gynec \& Ohst. 1965; 120:49.

23. Kirkpatrick CH, Wilson WEC, Talmage DW. Immunologic Studies in Human Organ Transplantation. I. Observation and Characterization of Suppressed Cutaneous Reactivity in Uremia. J Exp Med. 1964; 119:727. [PubMed: 14157027]

24. Küss R, Teinturier J, Millienz P. Quelques essais de greffes du rein chez l'homme. Mem Acad chir. 1951; 77:755. [PubMed: 14874917]

25. Lawrence W Jr, Miller DG, Isaacs M, Whitmore W. Criteria for Donor Selection in Human Kidney Homotransplantation. Transplantation. 1965; 3:452. [PubMed: 14285098]

26. MacLean LD, et al. Renal Homotransplantation Using Cadaver Donors. AMA Arch Surg. 1965; 91:288.

27. Marchioro TL, Brittain RS, Hermann G, Holmes JH, Waddell WR, Starzl TE. The Use of Living Donors for Renal Homotransplantation. AMA Arch Surg. 1964; 88:711. [PubMed: 14107027]

28. Marchioro TL, Porter KA, Dickinson TC, Faris TD, Starzl TE. Physiologic Requirements for Auxiliary Liver Homotransplantation. Surg, Gynec \& Obst. 1965; 121:17. [PubMed: 14314095]

29. Marchioro TL, Porter KA, Illingworth BI, Faris TD, Herrmann TJ, Sudweeks A, Starzl TE. The Specific Influence of Non-hepatic Splanchnic Venous Blood Flow upon the Liver. Surg Forum. 1965; 16:280. [PubMed: 5835158]

30. Marchioro TL, Huntley RT, Waddell WR, Starzl TE. The Use of Extracorporeal Perfusion for Obtaining Postmortem Grafts. Surgery. 1963; 54:900. [PubMed: 14087127]

31. McBride RA, Wheeler HB, Smith LL, Moore FD, Dammin GJ. Homotransplantation of the Canine Liver as an Orthotopic Vascularized Graft. Am J Path. 1962; 41:501. [PubMed: 19971018]

32. McKneally MF, Atai M, Oliveras FE, Kelly WD. Salvage of Cadaver Organs with Left Heart Bypass. Surg Forum. 1965; 16:272. [PubMed: 5319679]

33. Miller JFAP. Immunological Significance of the Thymus of the Adult Mouse. Nature. 1962; 195:1318.

34. Monaco AP, Wood ML, Russell PS. Adult Thymectomy: Effect on Recovery from Immunologic Depression in Mice. Science. 1965; 149:432. [PubMed: 17809411]

35. Moore FD, et al. Immunosuppression and Vascular Insufficiency in Liver Transplantation. Ann New York Acad Sc. 1964; 120:729. [PubMed: 14235286]

36. Moore FD, et al. One-Stage Homotransplantation of the Liver Following Total Hepatectomy in Dogs. Transplant Bull. 1959; 6:103. [PubMed: 13635834]

37. Moore FD, et al. Experimental Whole-Organ Transplantation of the Liver and of the Spleen. Ann Surg. 1960; 152:374. [PubMed: 13772284]

38. Mowbray JF, et al. Human Cadaveric Renal Transplantation. A Report of 20 Cases. Brit M J. 1965; 2:1387. [PubMed: 5321518]

39. Murray JE, Gleason R, Bartholomay A. Fourth Report of the Human Kidney Transplant Registry: 16 September 1964 to 15 March 1965. Transplantation. 1965; 2:684.

40. Murray JE, Harrison JH. Management of 50 Patients with Kidney Transplants, Including 18 Pairs of Twins. Am J Surg. 1963; 105:205. [PubMed: 13936774]

41. Murray JE, Merrill JP, Harrison JH, Wilson RE, Dammin GJ. Prolonged Survival of HumanKidney Homografts with Immunosuppressive Drug Therapy. New England J Med. 1963; 268:1315. [PubMed: 13936775]

42. Nies BA, Cohn R, Schrier SL. Erythremia After Renal Transplantation. New England J Med. 1965; 273:785. [PubMed: 5318491] 
43. Porter KA, Marchioro TL, Starzl TE. Pathological Changes in 37 Human Renal Homotransplants Treated with Immunosuppressive Drugs. Brit J Urol. 1965; 37:250. [PubMed: 14314426]

44. Riley CM. Thoughts About Kidney Homotransplantation in Children. J Pediat. 1964; 65:797.

45. Robin ED. Rapid Scientific Advances Bring New Ethical Questions. JAMA. 1964; 189:624. [PubMed: 14162577]

46. Rogers BO. Genetics of Transplantation in Humans. Dis Nerv System. 1963; 24(monograph suppl):3.

47. Simonsen M. Strong Transplantation Antigens in Man. Lancet. 1965; 1:415. [PubMed: 14238098]

48. Snell GD. The Genetics of Transplantation. J Nat Cancer Inst. 1953; 14:691. [PubMed: 13233822]

49. Starzl, TE. Experience in Renal Transplantation. Philadelphia: W. B. Saunders Company; 1964.

50. Starzl TE, Kaupp HA, Brock DR, Lazarus RE, Johnson RU. Reconstructive Problems in Canine Liver Homotransplantation, with Special Reference to the Postoperative Role of Hepatic Venous Flow. Surg, Gynec \& Obst. 1960; 111:733. [PubMed: 18979655]

51. Starzl TE, Kaupp HA, Brock DR, Linman J, Moss WT. Studies on the Rejection of the Transplanted Homologous Dog Liver. Surg, Gynec \& Obst. 1961; 112:135. [PubMed: 18979656]

52. Starzl TE, Marchioro TL, Hermann G, Brittain RS, Waddell WR. Renal Homografts in Patients with Major Donor-Recipient Blood Group Incompatibilities. Surgery. 1964; 55:195. [PubMed: 14121762]

53. Starzl TE, Marchioro TL, Holmes JH, Waddell WR. The Incidence, Cause and Significance of Immediate and Delayed Oliguria or Anuria After Human Renal Transplantation. Surg, Gynec \& Obst. 1964; 118:819. [PubMed: 14141329]

54. Starzl TE, Marchioro TL, Huntley RT, Rifkind D, Rowlands DT Jr, Dickinson TC, Waddell WR. Experimental and Clinical Homotransplantation of the Liver. Ann New York Acad Sc. 1964; 120:739. [PubMed: 14235287]

55. Starzl TE, Marchioro TL, Morgan WW, Waddell WR. A Technique for Use of Adult Renal Homografts in Children. Surg, Gynec \& Obst. 1964; 119:106. [PubMed: 14179336]

56. Starzl, TE.; Marchioro, TL.; Porter, KA. Progress in Homotransplantation of the Liver. In: Welch, C., editor. Advances in Surgery. Chicago: Year Book Publishers, Inc.; 1965. in press

57. Starzl TE, Marchioro TL, Porter KA, Moore CA, Rifkind D, Waddel WR. Renal Homotransplantation; Late Function and Complications. Ann Int Med. 1964; 61:470. [PubMed: 14218932]

58. Starzl TE, Marchioro TL, Porter KA, Taylor PD, Faris TD, Hermann TJ, Hlad CJ, Waddell WR. Factors Determining Short- and Long-Term Survival After Orthotopic Liver Homotransplantation in the Dog. Surgery. 1965; 58:131. [PubMed: 14305148]

59. Starzl TE, Marchioro TL, Rowlands DT Jr, Kirkpatrick CH, Wilson WEC, Rifkind D, Waddell WR. Immunosuppression After Experimental and Clinical Homotransplantation of the Liver. Ann Surg. 1964; 160:411. [PubMed: 14206848]

60. Starzl TE, Marchioro TL, Talmage DW, Waddell WR. Splenectomy and Thymectomy in Human Renal Homotransplantation. Proc Soc Exp Biol \& Med. 1963; 113:929. [PubMed: 14073145]

61. Starzl TE, Marchioro TL, Terasaki PI, Porter KA, Faris TD, Herrmann TJ, Vredevoe DL, Hutt MP, Ogden DA, Waddell WR. Chronic Survival After Human Renal Homotransplantation. Ann Surg. 1965; 162:749. [PubMed: 5319400]

62. Starzl TE, Marchioro TL, von Kaulla K, Hermann G, Brittain RS, Waddell WR. Homotransplantation of the Liver in Humans. Surg, Gynec \& Obst. 1963; 117:659. [PubMed: 14100514]

63. Szulman AE. The Histological Distribution of the Blood Group Substances A and B in Man. J Exper Med. 1960; 111:785. [PubMed: 13774694]

64. Tretbar LL, Beven EG, Hermann RE. Homotransplantation of an Auxiliary Dog Liver into the Pelvis-Effect of Portacaval Shunt in the Prevention of Liver Atrophy. Surg Forum. 1965; 16:219. [PubMed: 5319662]

65. Von Kaulla KN, Kaye H, von Kaulla E, Marchioro TL, Starzl TE. Changes in Blood Coagulation in Hepatectomy and Liver Transplantation. AMA Arch Surg. 1966; 92:71. [PubMed: 5322193] 
66. Vredevoe DL, et al. Serotyping of Human Lymphocyte Antigens. III. Long Term Kidney Homograft Survivors. Transplantation. Submitted to.

67. Welch CS. A Note on the Transplantation of the Whole Livers in Dogs. Transplant Bull. 1955; 2:54.

68. Wilson WEC, Kirkpatrick CH, Talmage DW. Suppression of Immunologic Responsiveness in Uremia. Ann Int Med. 1965; 62:1.

69. Woodruff, MFA. Some Remarks at the National Academy of Science Symposium on Human Renal Transplantation. Washington, D. C.: May 17. 1965 


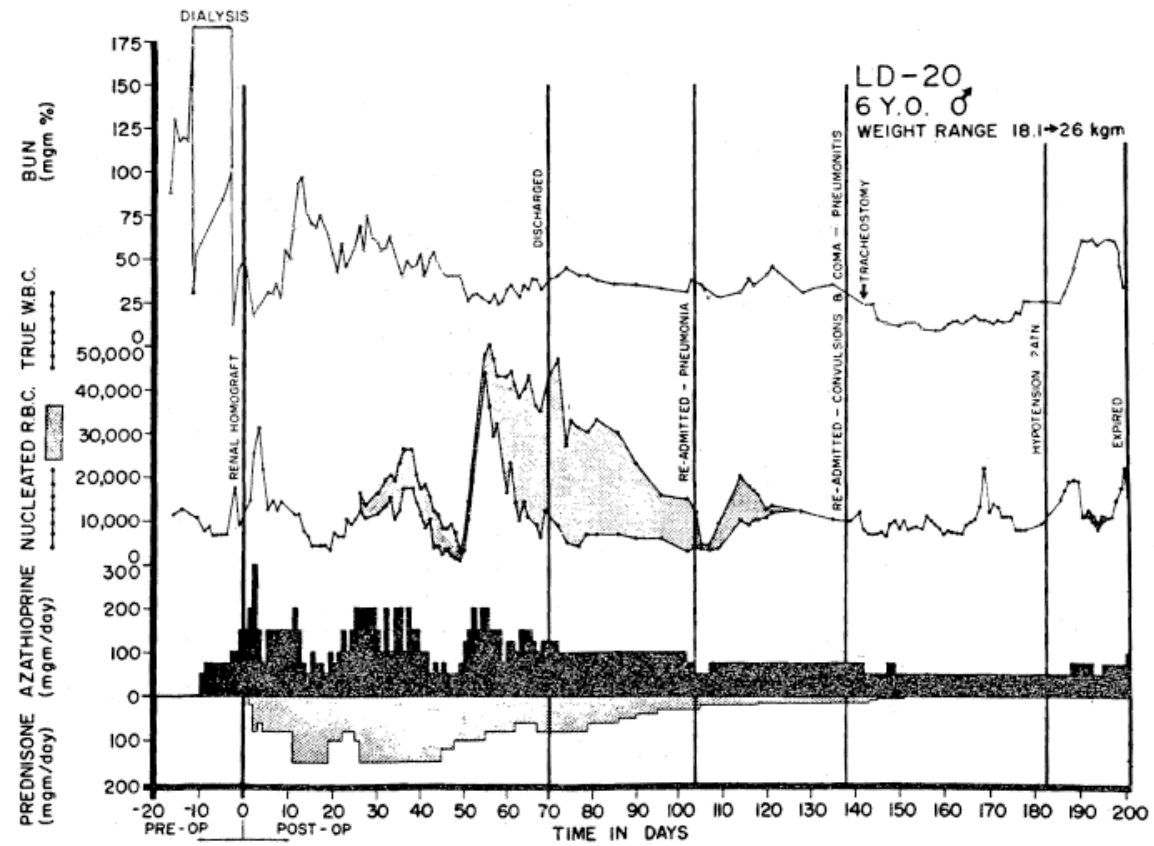

Figure 23.

Course of a 6-year-old patient who died almost 7 months after renal homotransplantation. The maternal donor was $\mathrm{A}$ - blood type; the patient was $\mathrm{O}+$. In addition to the immunosuppressive therapy indicated, actinomycin $\mathrm{C}$ was administered intravenously every 5 to 10 days throughout most of the early postoperative period. The terminal rise in blood urea nitrogen level was thought to be secondary to hypotension. Note the striking normoblastemia in the second to fourth postoperative months. This phenomenon was studied in detail by Nies. ${ }^{42}$ 


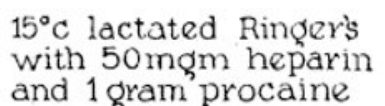

and 1 gram procaine
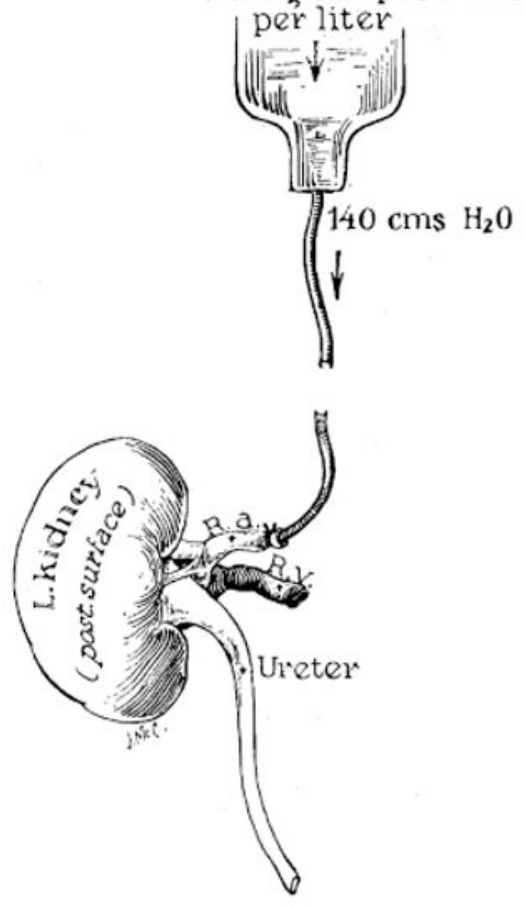

Figure 24.

Technique of perfusion of kidneys with cold lactated Ringer's solution. Without the addition of procaine, great difficulty may be encountered in obtaining sufficient flow, possibly owing to afferent arteriolar constriction. Usually only 200 to $500 \mathrm{cc}$. is required to cool the organ to 15 to $20^{\circ} \mathrm{C}$ (By permission of Surgery, 55:195, 1964.) 


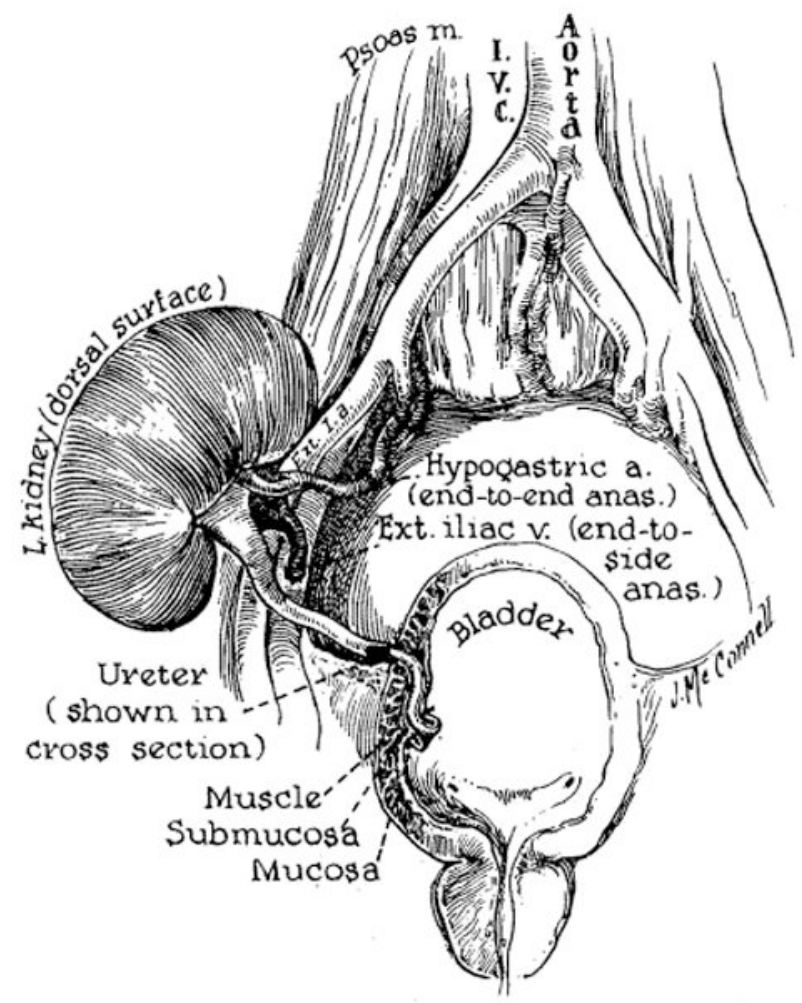

Figure 25.

Usual method of renal transplantation. The opposite donor kidney is revaseularized in the extraperitoneal space with a hypogastric to renal arterial anastomosis, and with an end-toside connection of the renal to external iliac veins. A ureteroneocystostomy as shown provides satisfactory urinary drainage. Alternatively, a ureteroureterostomy or ureteropyelostomy may be performed. (By permission of J.A.M.A., 187:734, 1964.) 


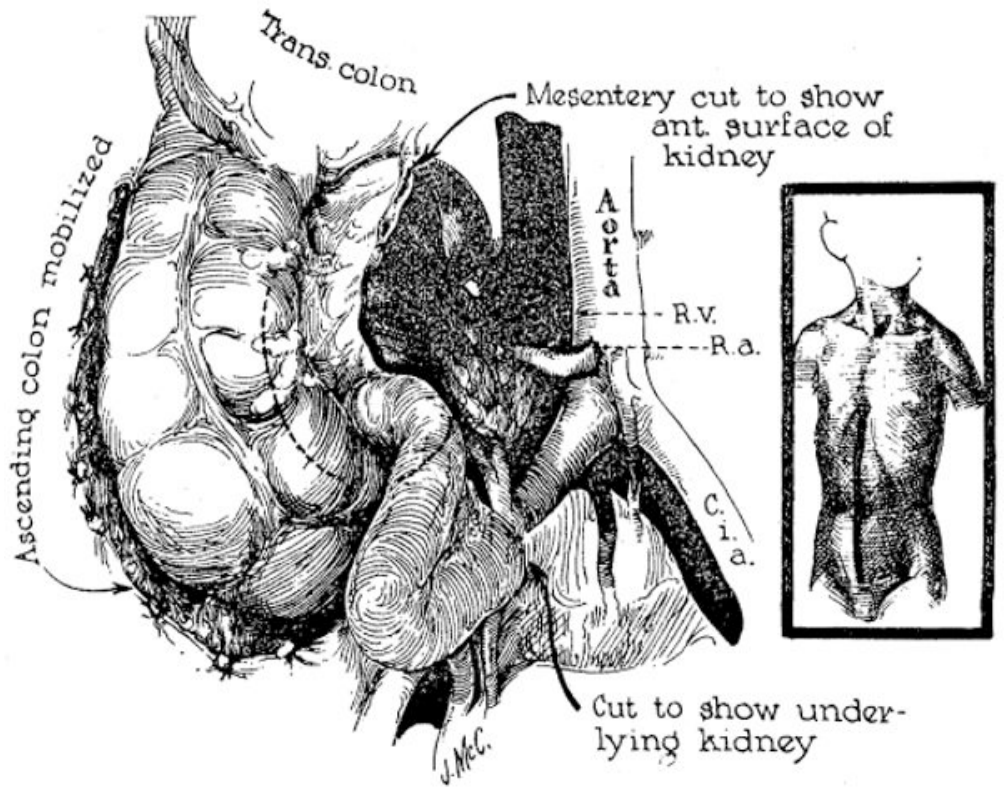

Figure 26.

Method for transplantation of an adult kidney to a child recipient. The operation is done transperitoneally through a complete midline incision (insert). The ascending colon is reflected to the left, and the renal artery and vein are anastomosed to the great vessels of the recipient as depicted. (By permission of Surg., Gynec. \& Obst., 119:106, 1964.) 


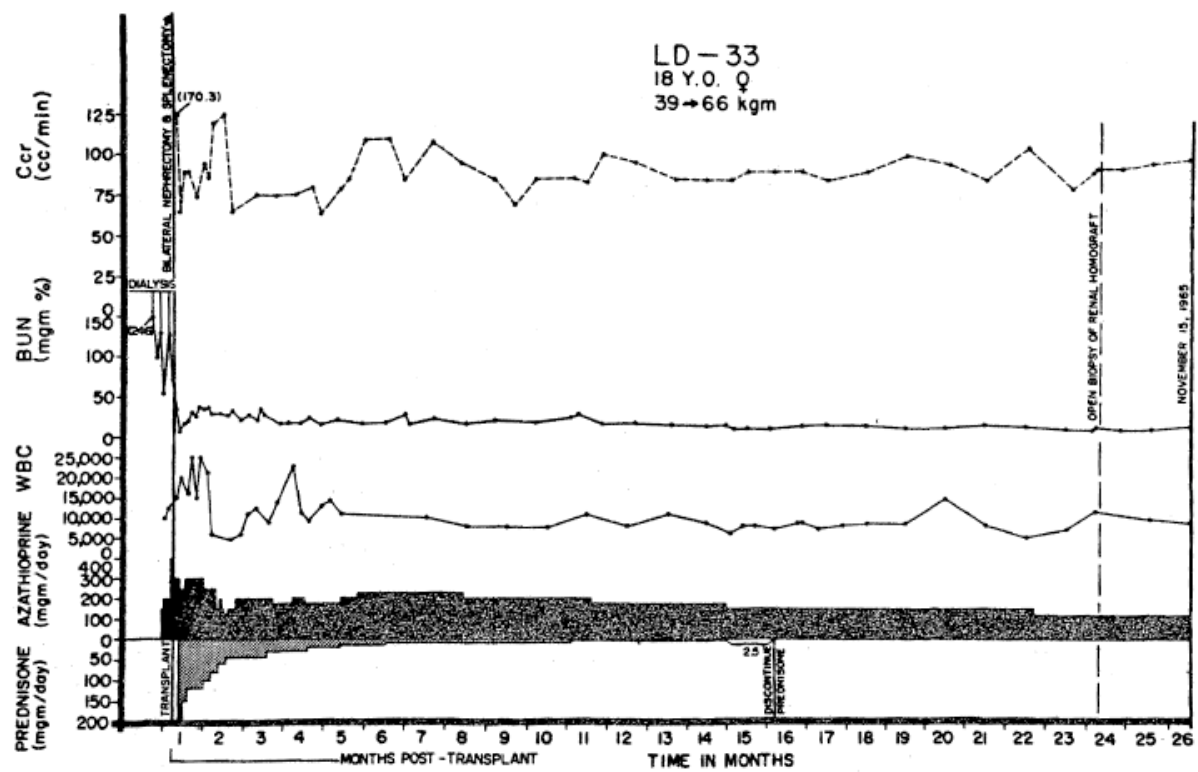

Figure 27.

Typical course after renal homotransplantation. The recipient was an 18-year-old girl. The donor was her mother. Both were A+ blood type. Note the mild early rejection, which reversed after the addition of prednisone to the initial azathioprine therapy. Ultimately it was possible to stop steroid treatment. A 2-year post-transplant biopsy was normal. Thymectomy had not been performed. 


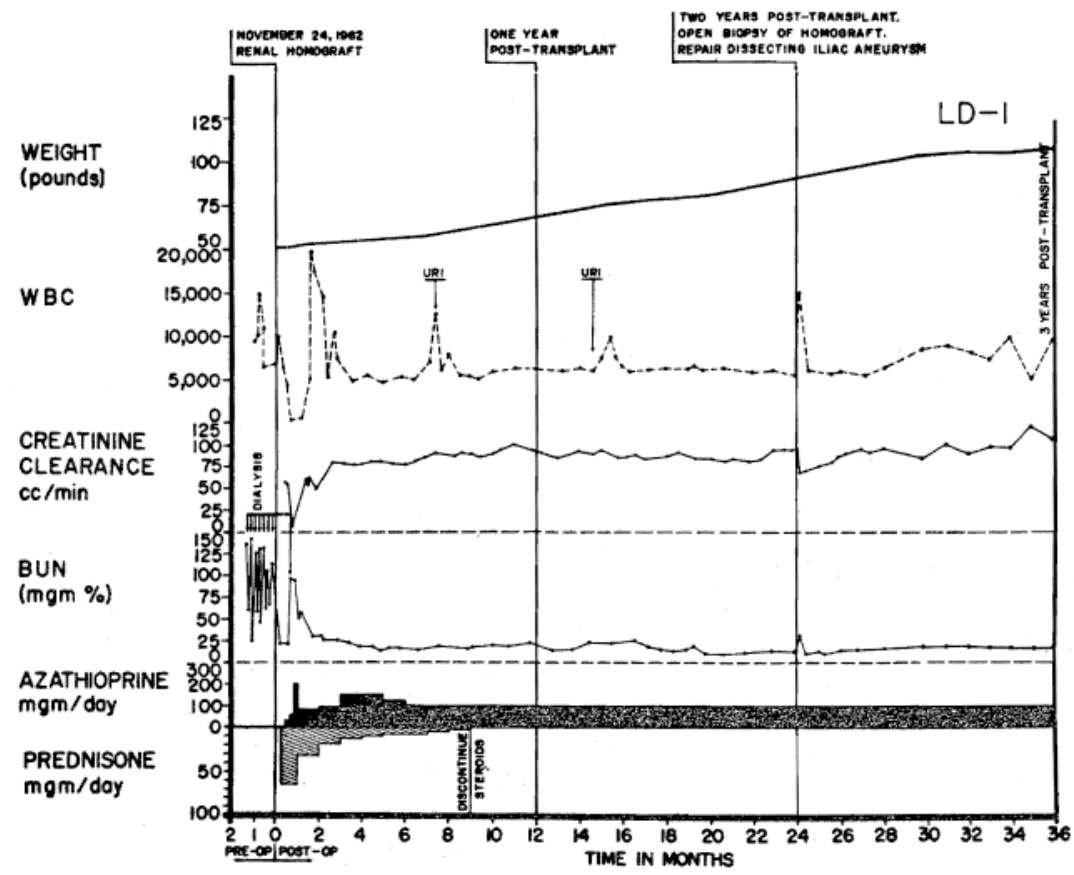

Figure 28.

Course of a patient who received a renal homograft from his mother at the age of 12 years; both were $\mathrm{B}+$ blood type. Initial immunosuppression was with total body irradiation, a total divided dose of $400 \mathrm{R}$ being given before and just after homotransplantation. Despite profound leukopenia, a severe rejection developed. This was controlled with steroids, azathioprine and actinomycin $\mathrm{C}$. The 2-year biopsy revealed numerous abnormalities, despite which essentially normal function has persisted for more than a subsequent year. The patient had splenectomy and thymectomy prior to transplantation. 


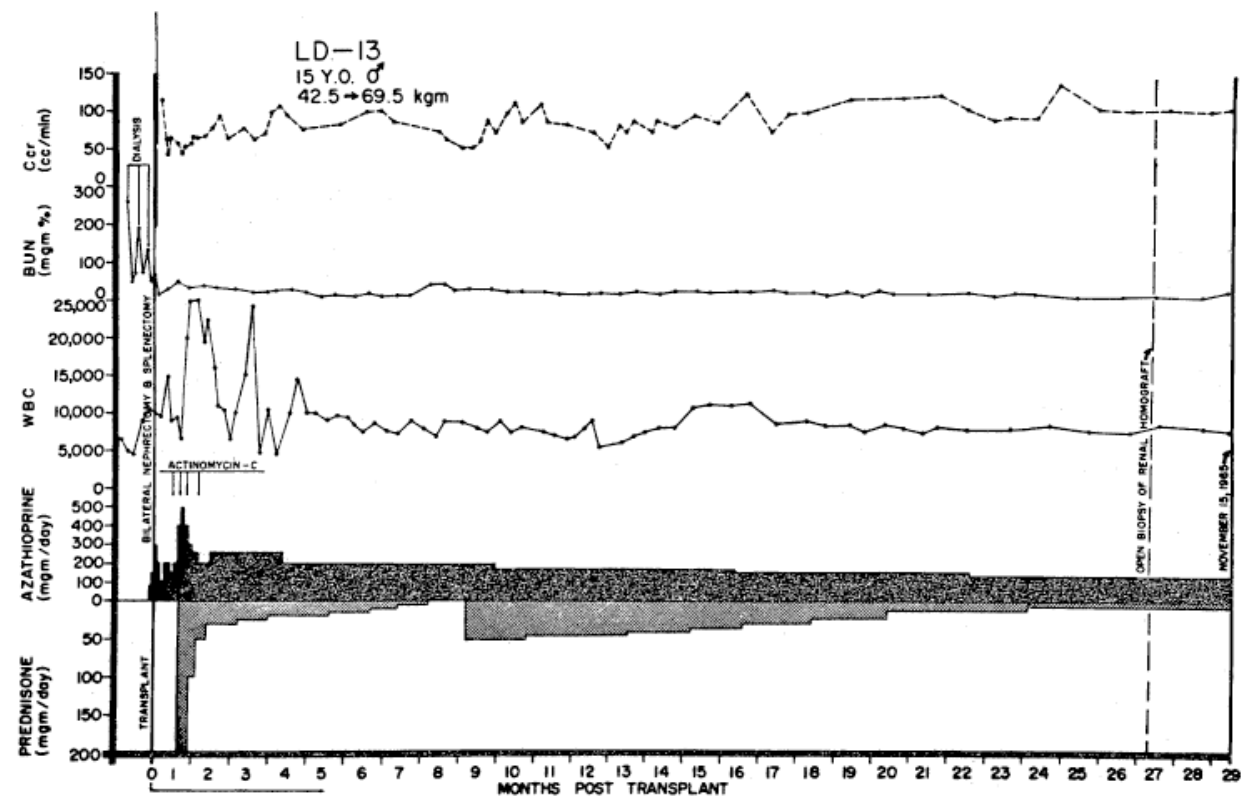

Figure 29.

Course of a patient who received a renal homograft from his mother on July 3, 1963. Both donor and recipient were $\mathrm{A}+$ blood type. Discontinuance of steroids $71 / 2$ months after operation apparently resulted in a slow delayed rejection, with a decline of creatinine clearance and a rise in blood urea nitrogen level. The resumption of steroid therapy reversed this trend, and the subsequent course has been stable. Nevertheless numerous abnormalities were present in the 2-year biopsy. 


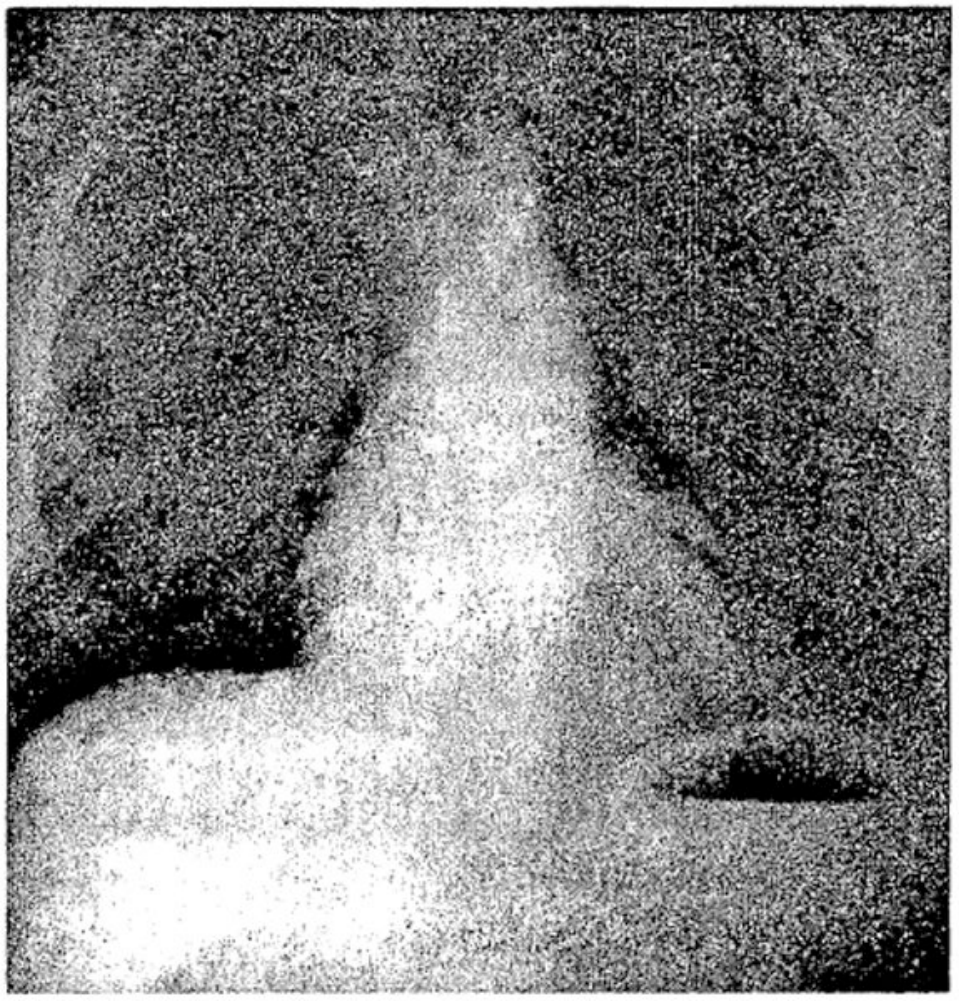

Figure 30.

Terminal pneumonia which was subsequently demonstrated at autopsy to be due to Pneumocystis carinii. Histologic evidence of cytomegalic inclusion disease was also present. The transplantation was carried out on July 26, 1963, and the patient died of pulmonary insufficiency on November 12,1963 . The x-ray film was obtained on November 11,1963 . Renal insufficiency was not a factor in the unfavorable outcome. 


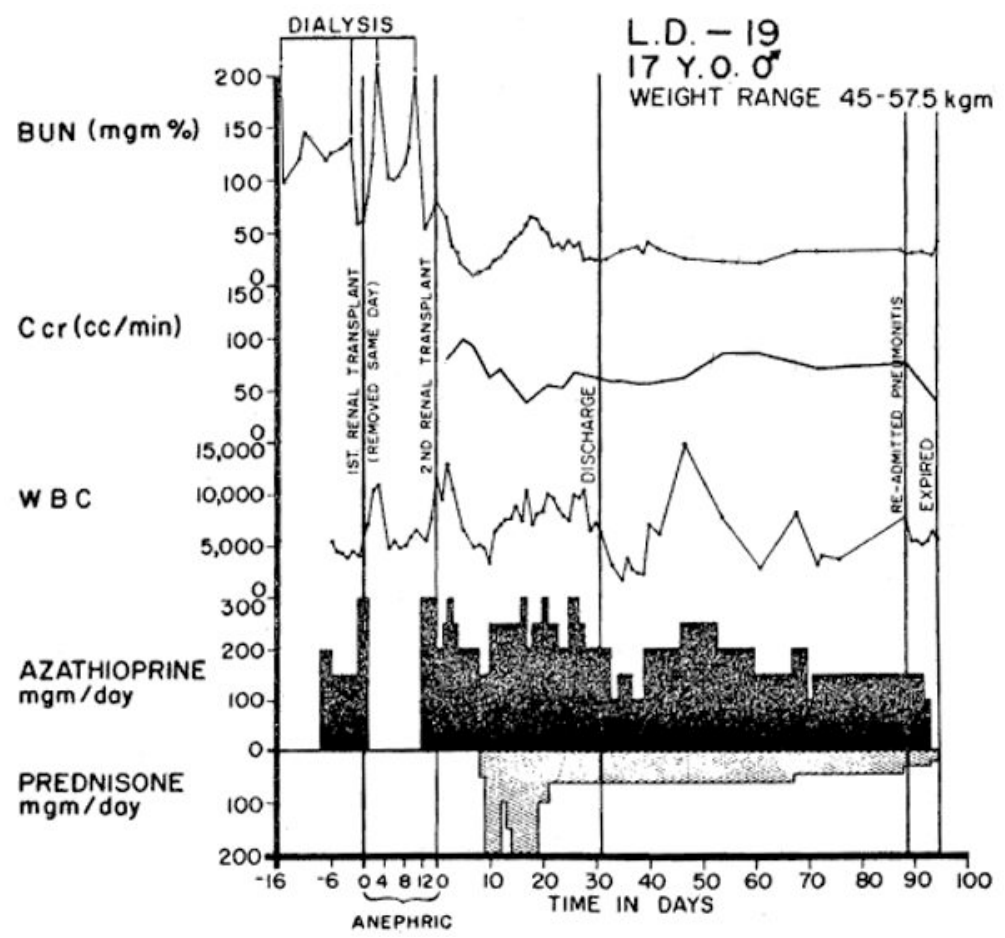

Figure 31.

Course of an unsuccessful case of renal homotransplantation. The initial homograft failed immediately because of a blood group incompatibility; the mother was A blood type and the patient was $\mathrm{O}$. The definitive homograft was from an unrelated donor of $\mathrm{O}$ blood group. Death occurred from pulmonary insufficiency caused by Pneumocystis carinii pneumonia. The patient's chest x-ray is shown in Figure 30. Note that renal function was well maintained until just before death. 


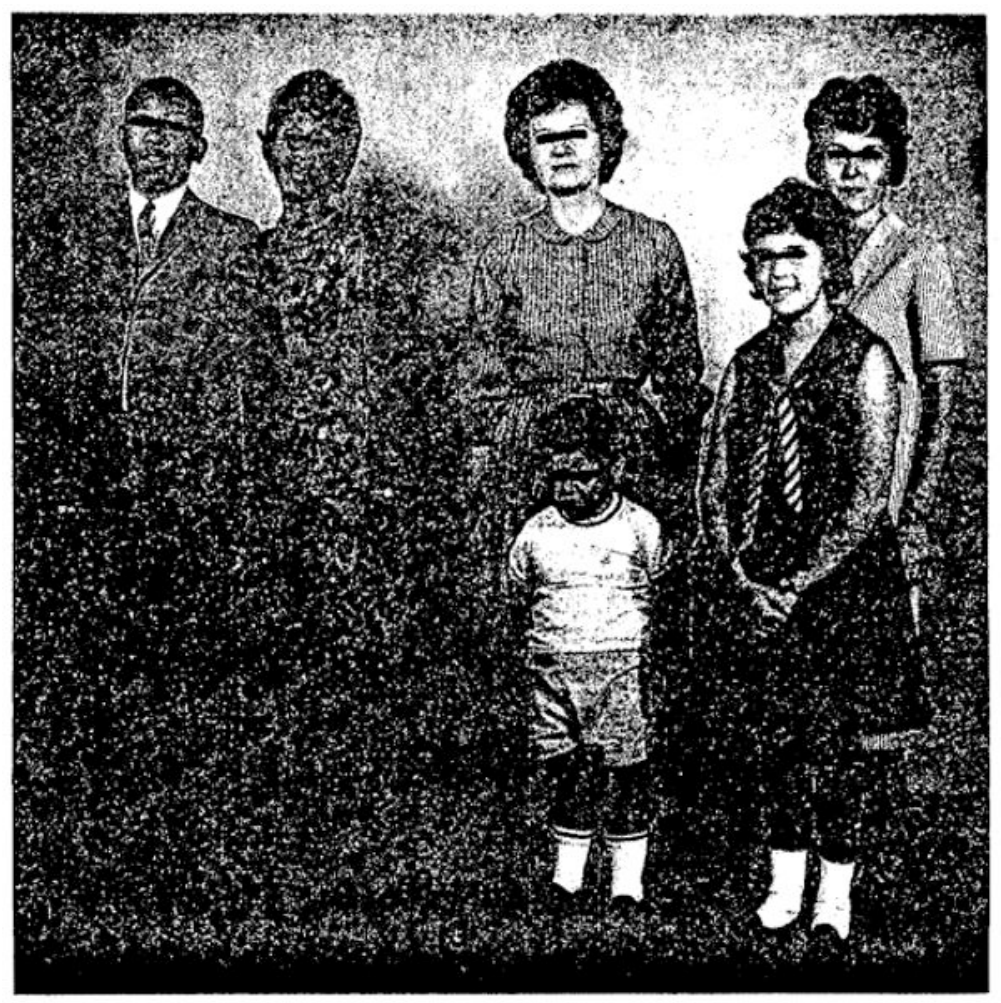

Figure 32.

Three children (and their donors) who have survived for 2 to 3 years after renal homotransplantation. The recipients on the left and right have not received steroid therapy for $2^{1 / 2}$ years and 1 year respectively. Their growth has been normal. The child in the middle, who is receiving $7.5 \mathrm{mg}$. of prednisone per day, has grown only slightly and has other evidence of hypercorticism. 


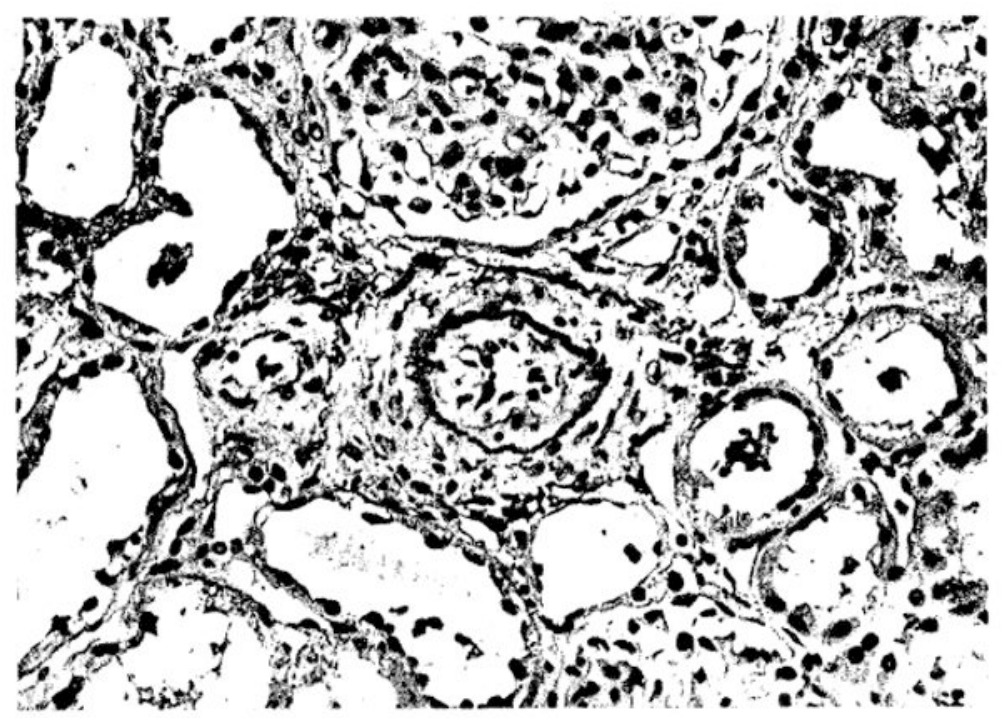

Figure 33.

Biopsy of renal homograft from patient LD 1 at 2 years. There is intimal thickening of an interlobular artery. Adjacent tubules are lined by flattened atrophic epithelium. Weigert's elastic. $\times 350$. 


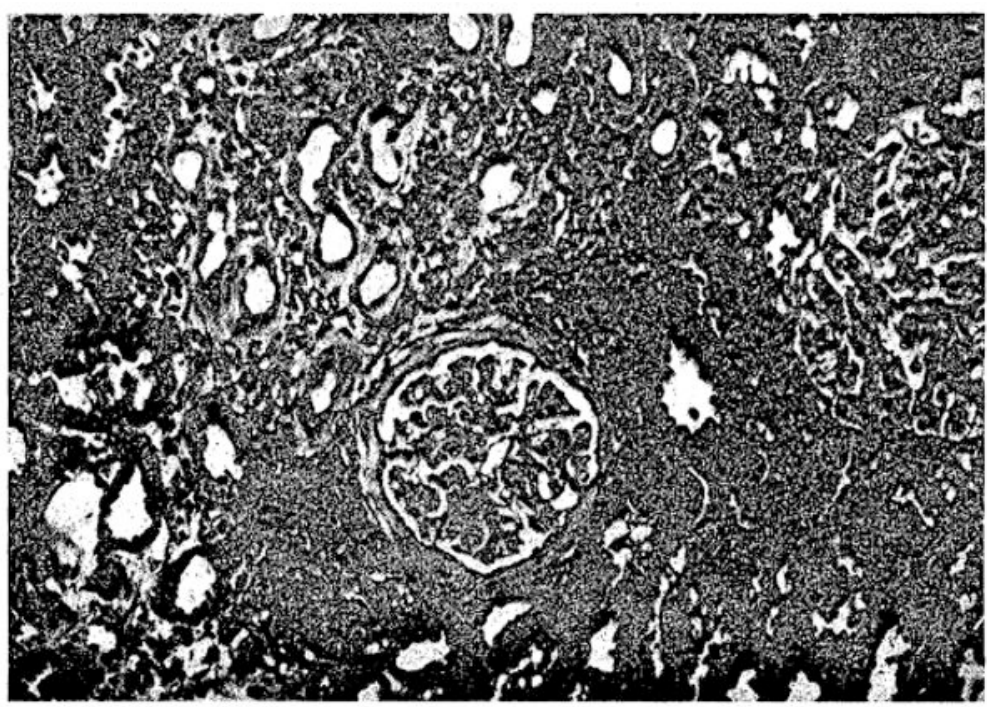

Figure 34.

Biopsy of renal homograft from patient LD 13 at 1 year 9 months. A small area of ischemic tubular atrophy can be seen, associated with interstitial fibrosis, dense infiltration with mononuclear cells and periglomerular fibrosis. H \& E. × 300 . 


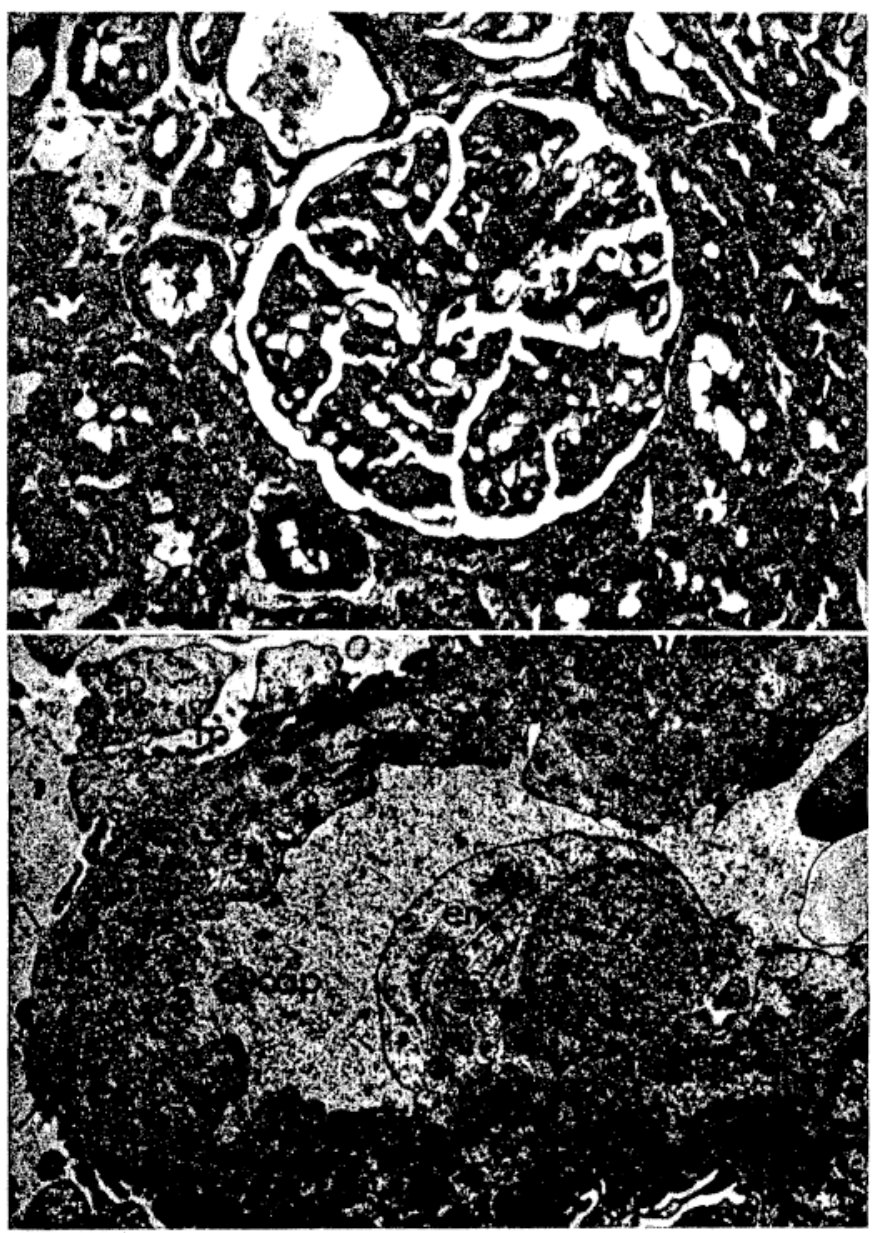

Figure 35.

Biopsy of renal homograft from patient LD 41 at 1 year 10 months. Upper, By light microscopy the glomerular capillary basement membrane is seen to be diffusely thickened as in membranous glomerulonephritis. H \& E. $\times 350$. Lower, Electron microscopy of part of one of the glomerular capillary loops shows that the basement membrane thickening $(\mathrm{bm})$ is caused by irregular deposits of electron-dense material beneath the endothelium (en), unlike membranous glomerulonephritis, in which the deposits are usually on the epithelial side of the membrane. A few of the epithelial foot processes $(f p)$ are fused (arrows). cap, Capillary lumen; ep, part of epithelial cell. Epon; $\mathrm{Pb}$ stain. $\times 8,950$. 


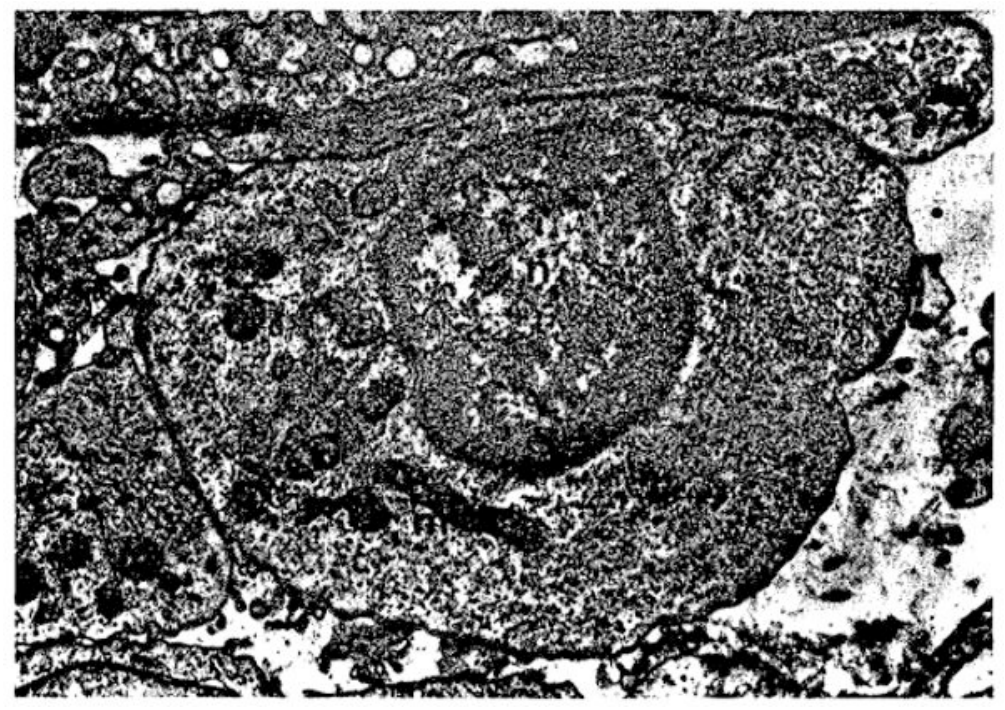

Figure 36.

Electron micrograph of part of biopsy of renal homograft from patient LD 34 at 1 year 11 months. A large lymphoid cell, its cytoplasm full of free ribosomes, lies in the interstitium. $t u$, Part of proximal tubule; $b m$, tubular basement membrane; $n$, nucleus of lymphoid cell; $m$, mitochondrion. Spon; Pb stain. $\times 12,000$. 


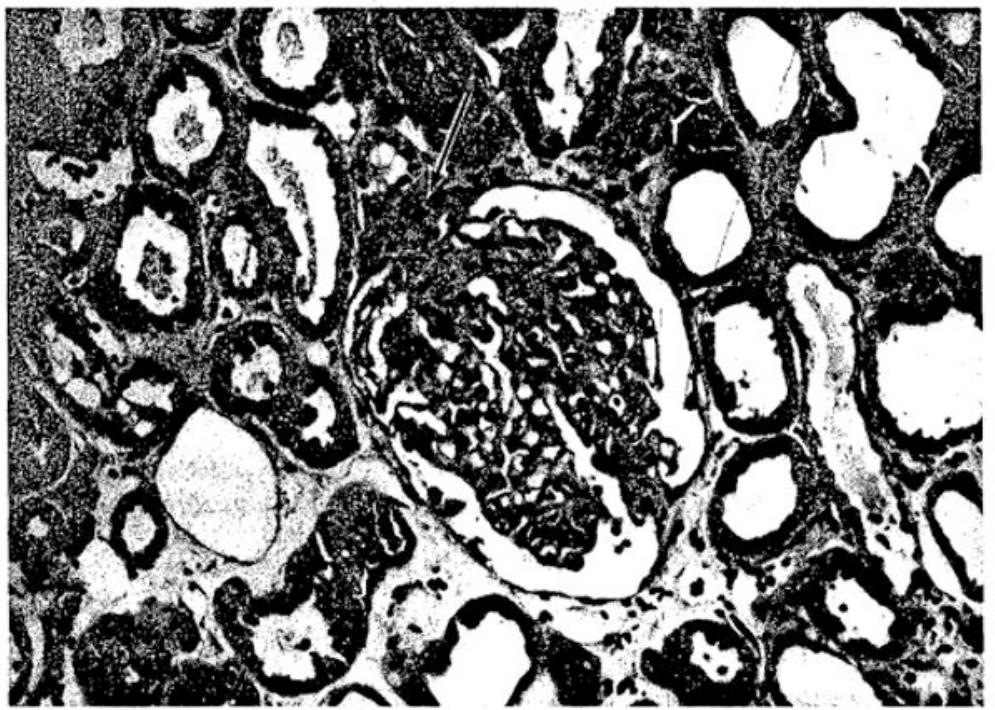

Figure 37.

Biopsy of renal homograft from patient LD 41 at 1 year 10 months. The juxtaglomerular apparatus (arrow) is hyperplastic. There is thickening of the glomerular capillary basement membranes and an adhesion between tuft and Bowman's capsule. Interstitial fibrosis and tubular atrophy are present around the glomerulus. H \& E. $\times 300$. 


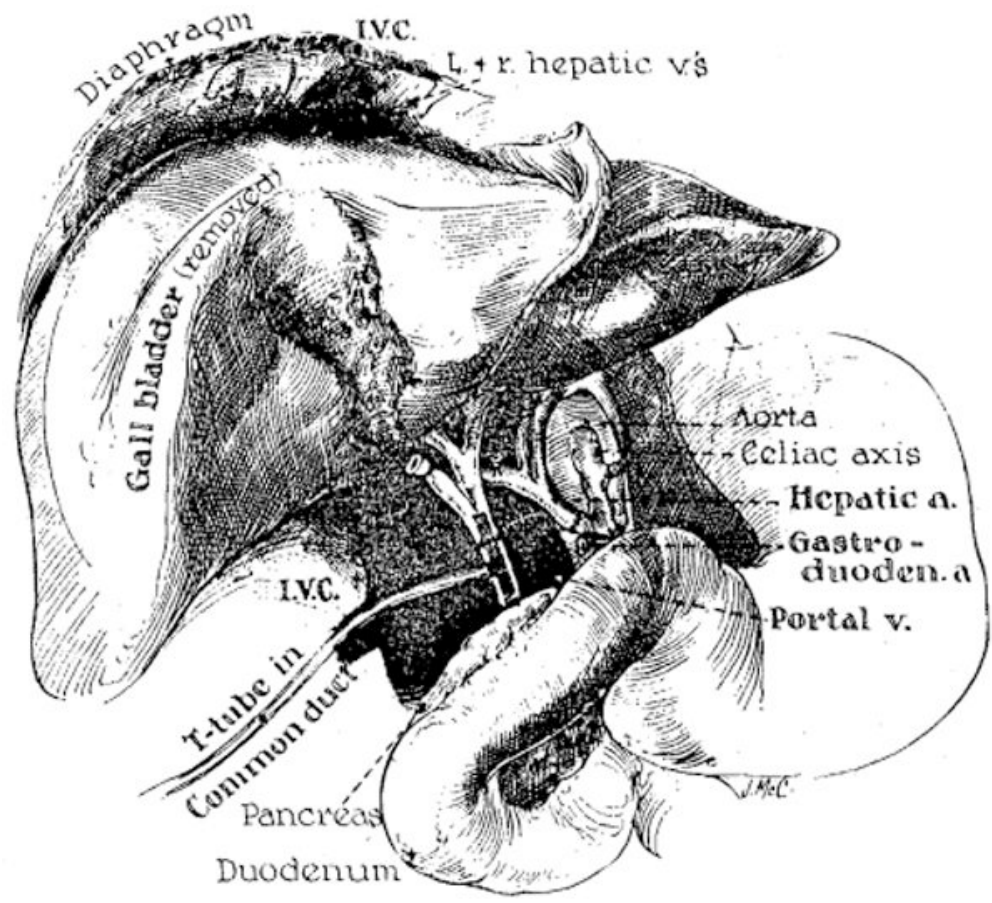

Figure 38.

Completed human orthotopic liver homograft. Note that all structures entering and leaving the liver are reconstructed in a normal anatomic manner. (By permission of Ann. New York Acad. Sc., 120:739, 1964.) 


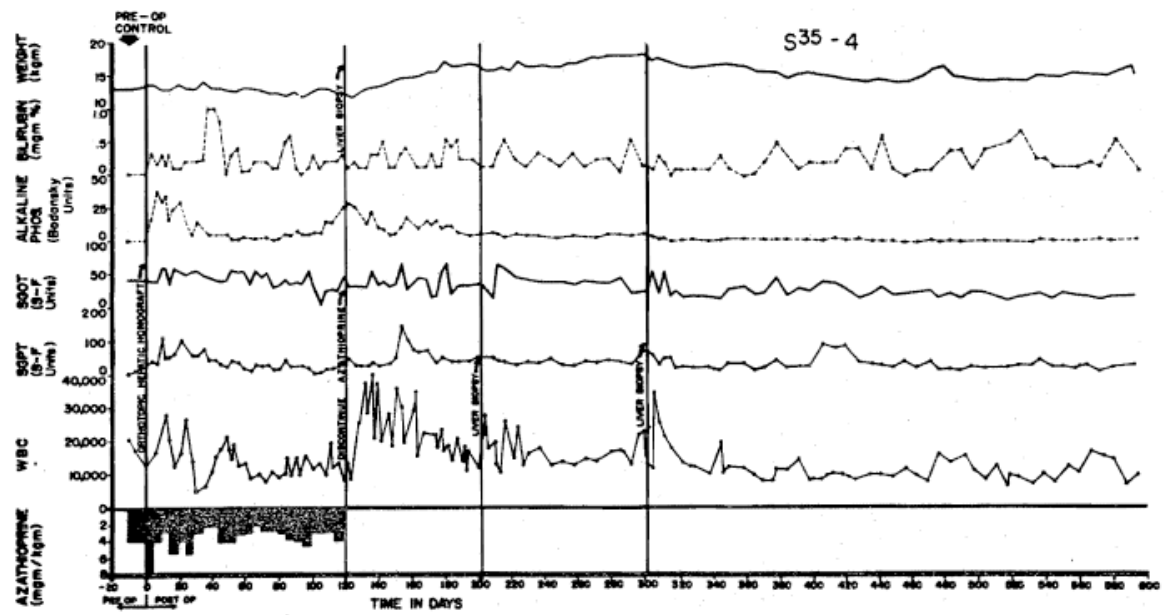

Figure 39.

Course of an animal after orthotopic homotransplantation of the liver. Overt clinical rejection has never been observed, and all 3 postoperative liver biopsies have been normal (see Fig. 41, lower). The operation was performed on March 23, 1964, and the animal is in good health 20 months later. Note that immunosuppression was discontinued after 4 postoperative months without subsequent deterioration of liver function. 


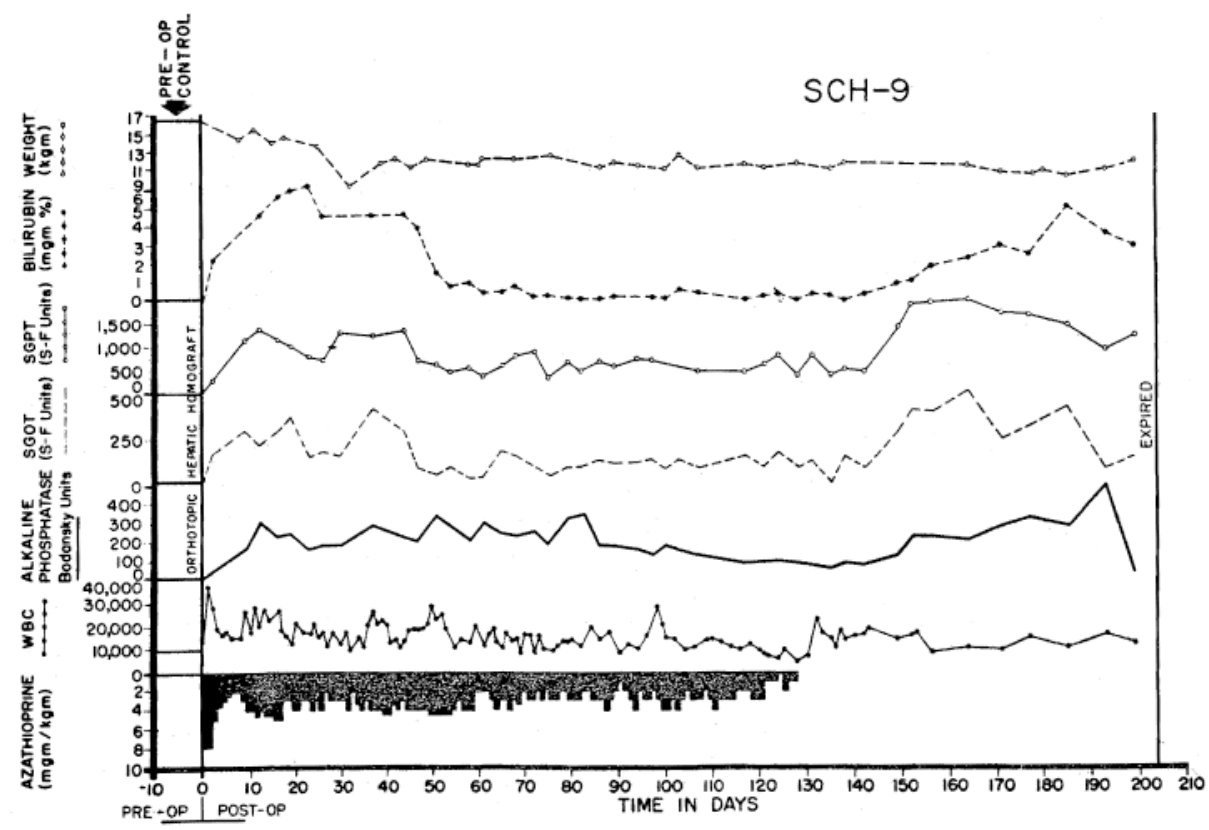

Figure 40.

Clinical course of a dog after orthotopic homotransplantation of the liver. Note the early evidence of rejection, which reversed without intensification of immunosuppressive therapy. Azathioprine was stopped after 4 months with a subsequent slow rejection. The direct cause of death, 204 days after operation, was a perforated esophagogastric ulcer. 


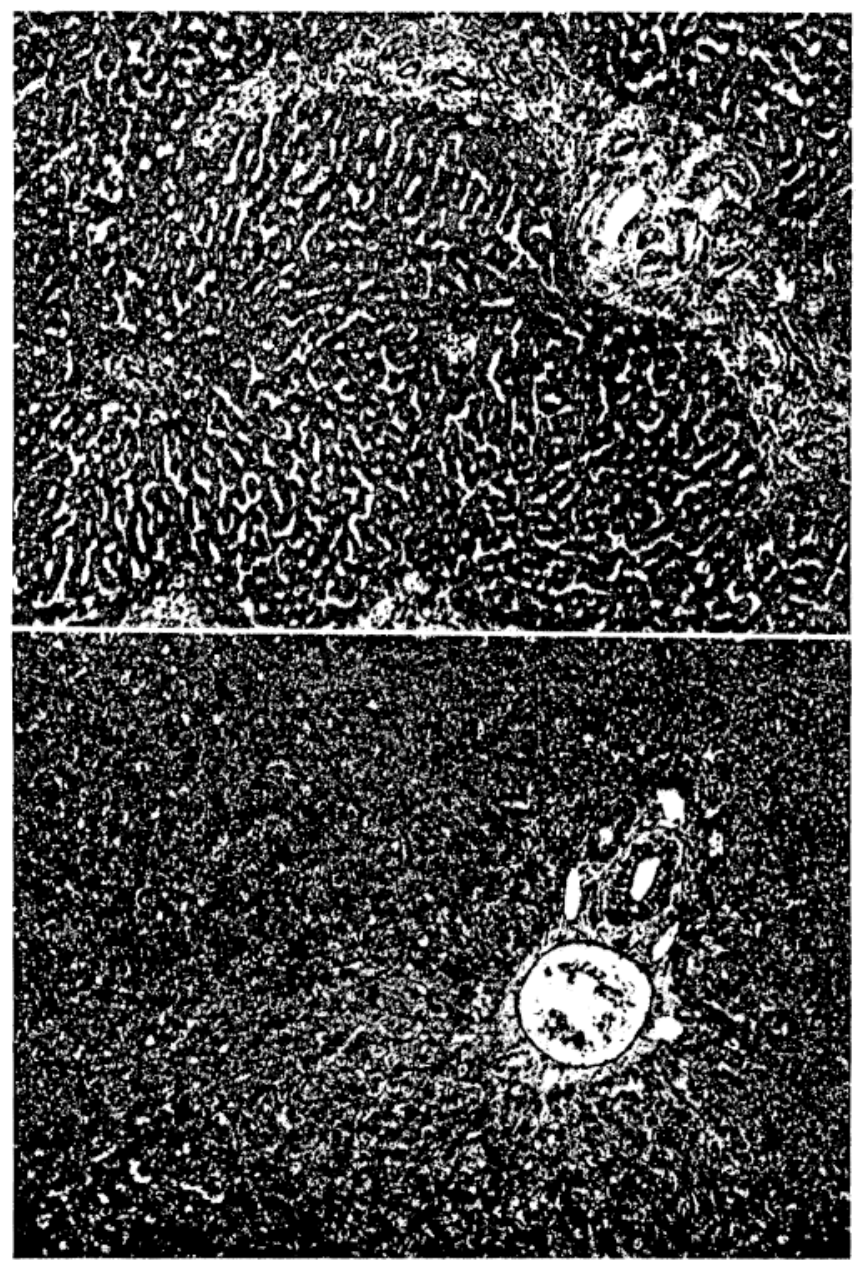

Figure 41.

Histologic appearance of chronically tolerated orthotopic liver homografts. Upper, Biopsy after 123 days. There is some increase in portal connective tissue, proliferation of small biliary ductules, and a slight cellular infiltration. This animal then had azathioprine therapy discontinued, with subsequent survival for 7 months. The dog ultimately died of a perforated duodenal ulcer. Lower, Biopsy of a histologically normal orthotopic homograft after 302 days' residence in the host. At the time of biopsy the animal had not received immunosuppressive therapy for 6 months. The dog is still alive more than 20 months after operation; The clinical course is depicted in Figure 39. H \& E. $\times 40$. 


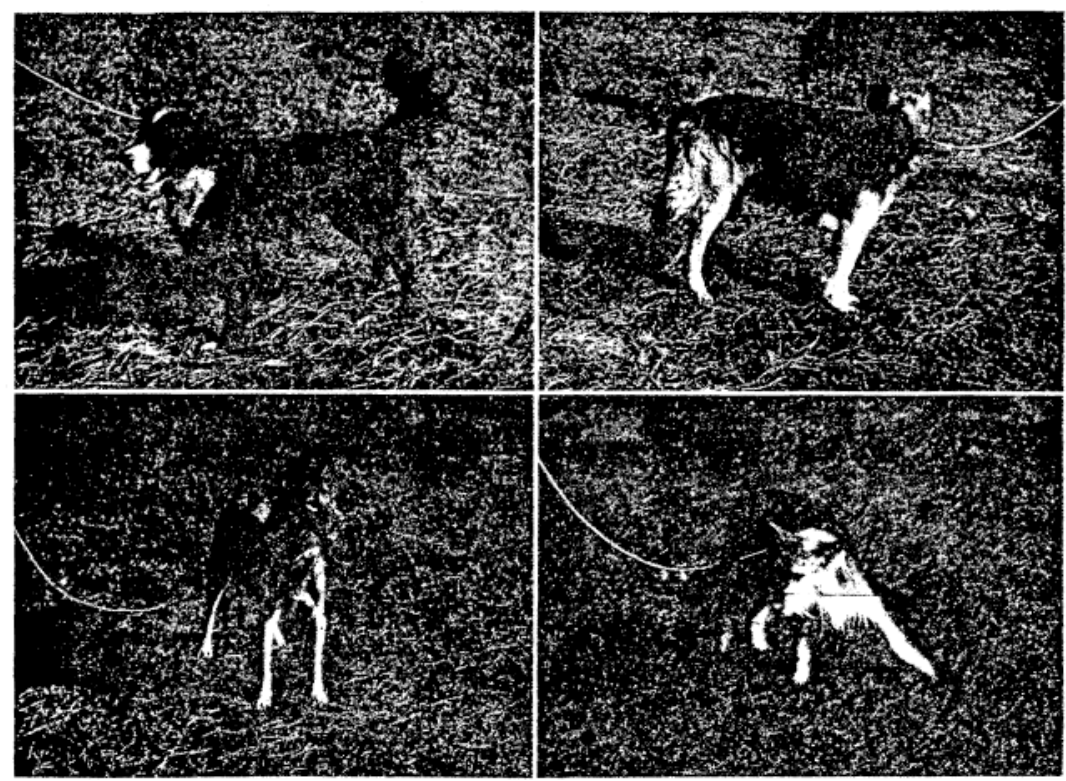

Figure 42.

Four dogs who are still alive 1 year or longer after orthotopic liver transplantation. In each case immunosuppression was discontinued after 4 months. The animals have had a total post-transplant longevity of $376,487,504$ and 610 days. 


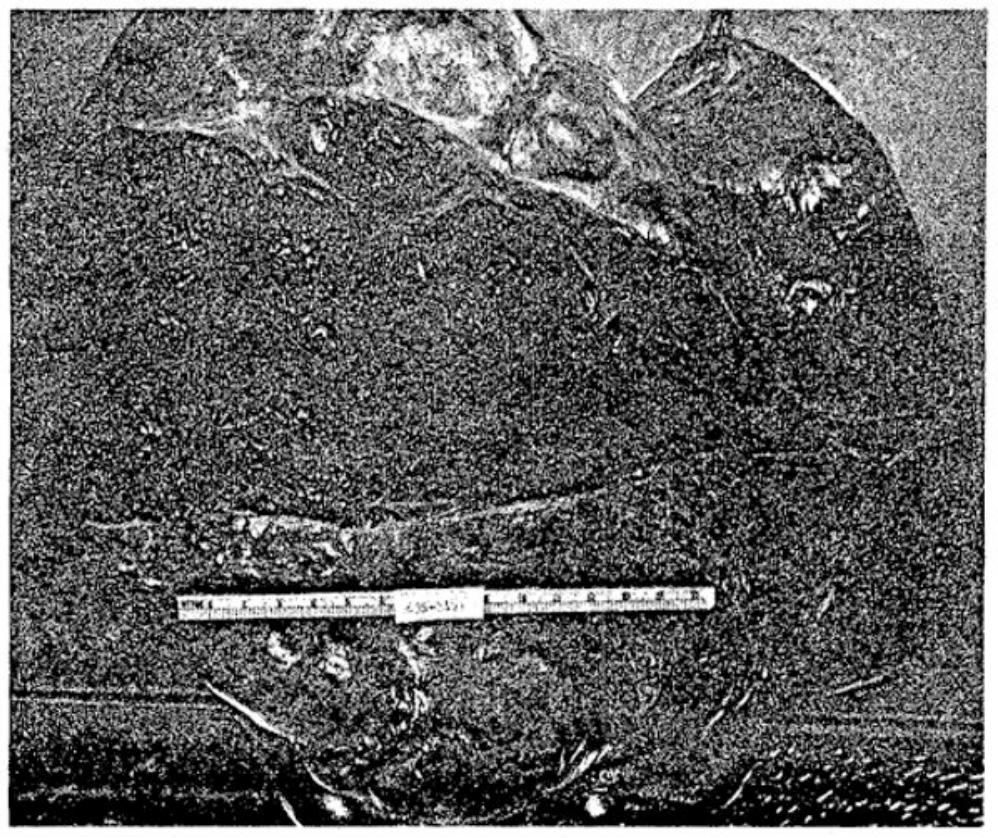

Figure 43.

Bulky hepatoma removed from a 29-year-old woman who received an orthotopic liver transplant. Only a rim of normal liver tissue remains. The patient survived for 23 days after the transplant. 


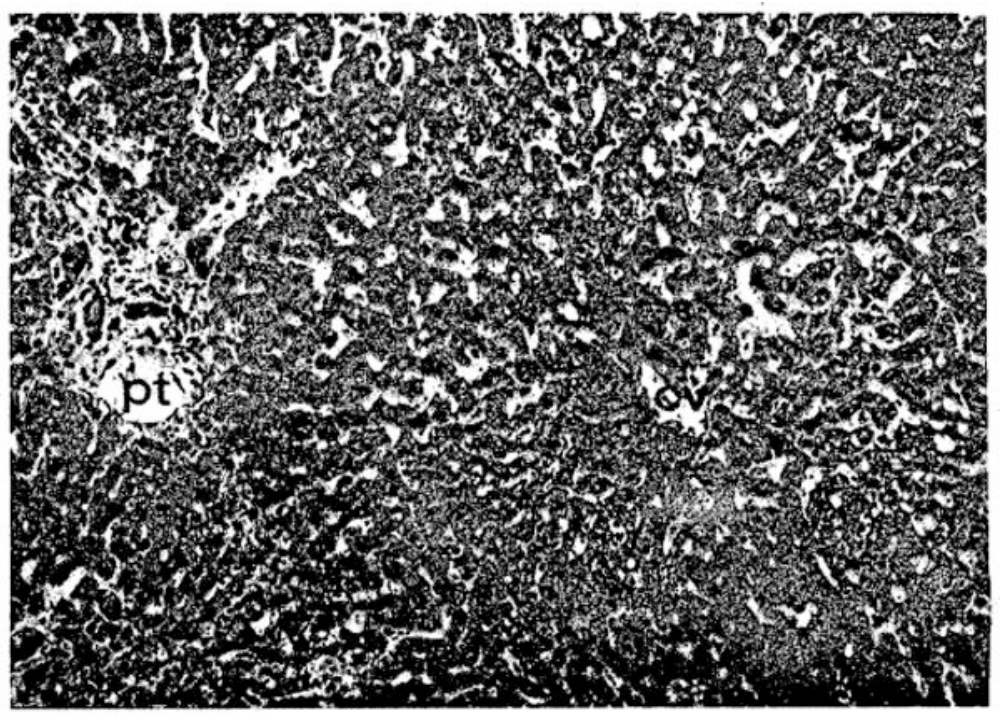

Figure 44.

Orthotopic human hepatic homograft at 22 days. There is good preservation of liver cells and lobular structure. The portal tract ( $p t$ ) contains a few infiltrating mononuclear cells, $c v$, Central vein. H \& E. $\times 90$. 


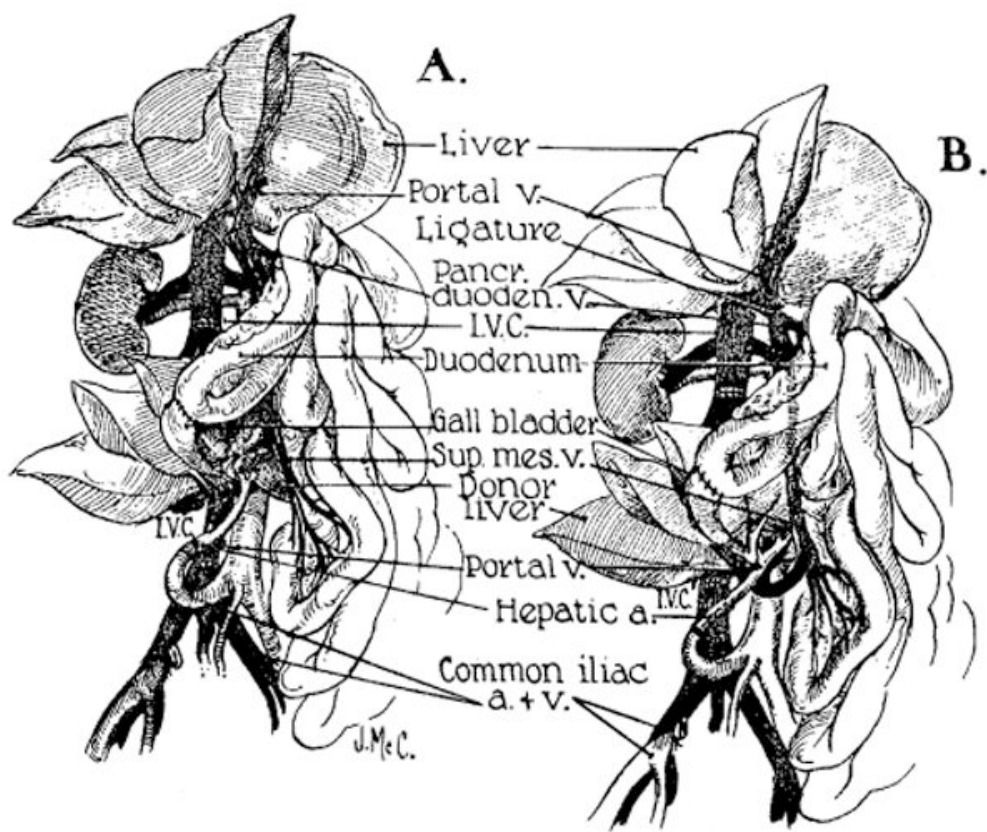

Figure 45.

Experimental auxiliary homotransplantation of the liver. A, Welch's original operation. Note that the portal venous inflow is derived from the terminal vena cava and that the hepatic arterial supply is from the iliac artery. The auxiliary liver undergoes rapid atrophy beginning within 2 weeks after operation. $B$, Modification of auxiliary homotransplantation in which the homograft portal vein is revascularized from the distal splanchnic venous system.

Retrograde splanchnic venous flow through the homograft is promoted by proximal ligation of the recipient portal vein. With this method of revascularization the homograft atrophy is avoided; instead, the recipient's own liver shrinks. (By permission of Surg., Gynec. \& Obst., 121:17, 1965). 

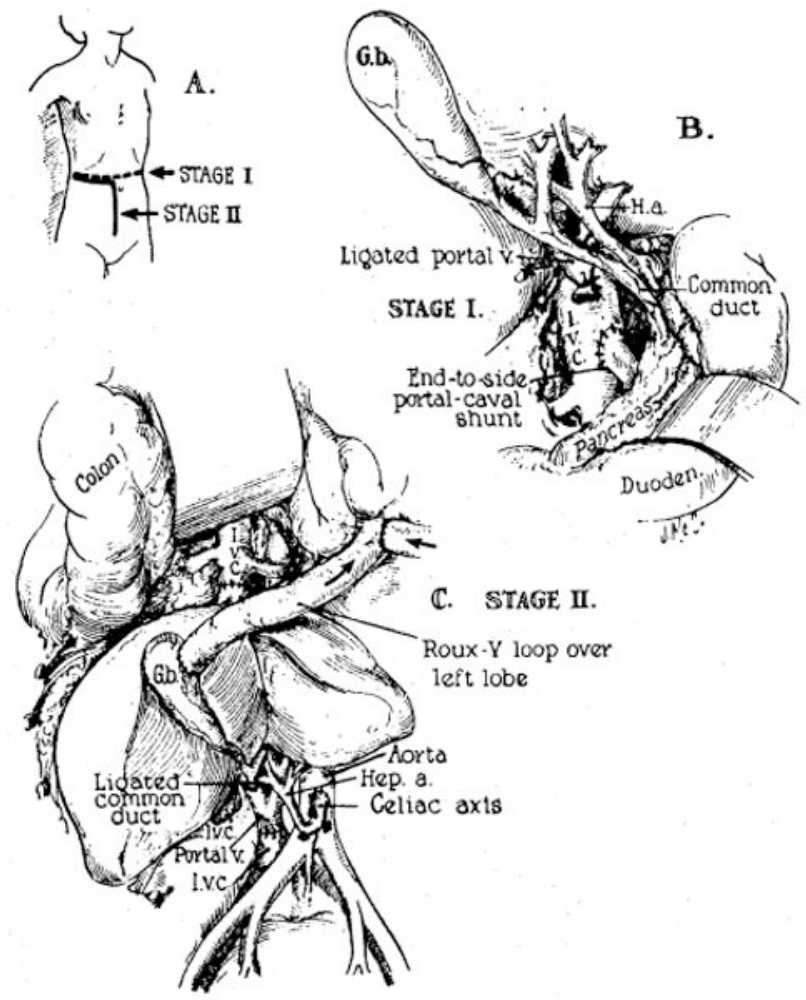

Figure 46.

Method of auxiliary liver transplantation which has received a clinical trial. The procedure has been used twice at the University of Colorado Medical Center in patients with terminal Laennec's cirrhosis. $A, B$, First-stage portacaval anastomosis is performed. This will usually be necessary for control of variceal hemorrhage. $C$, Revascularization of the auxiliary liver in the right paravertebral gutter. 


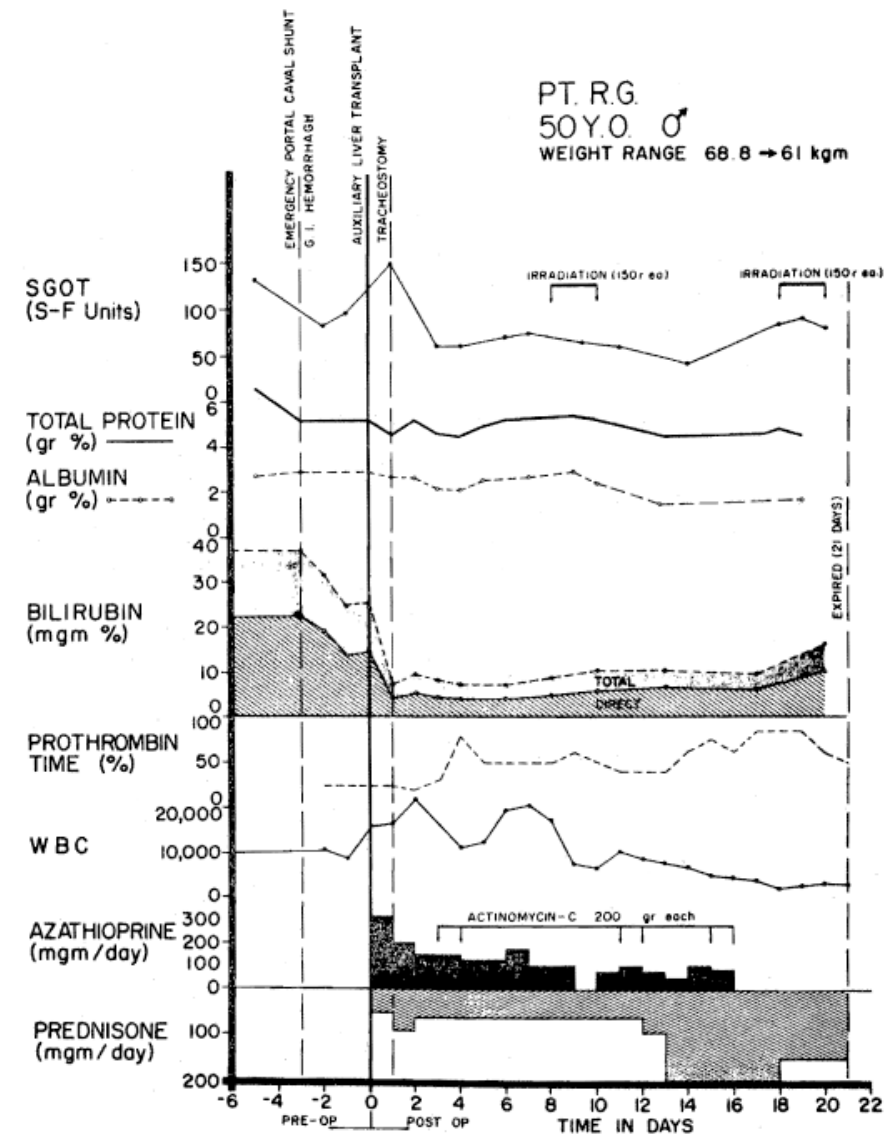

Figure 47.

Clinical course of a patient with Laennec's cirrhosis who received an auxiliary liver homograft. The preliminary portacaval shunt controlled massive hemorrhage from esophageal varices. Note the evidence of function of the transplanted liver with a fall in the serum bilirubin and a sustained improvement in the prothrombin time. The bilirubin had begun to rise secondarily at the time of death from septic complications. The donor was a 77-year-old man who died of a cardiac arrest. Both were A + blood type. 


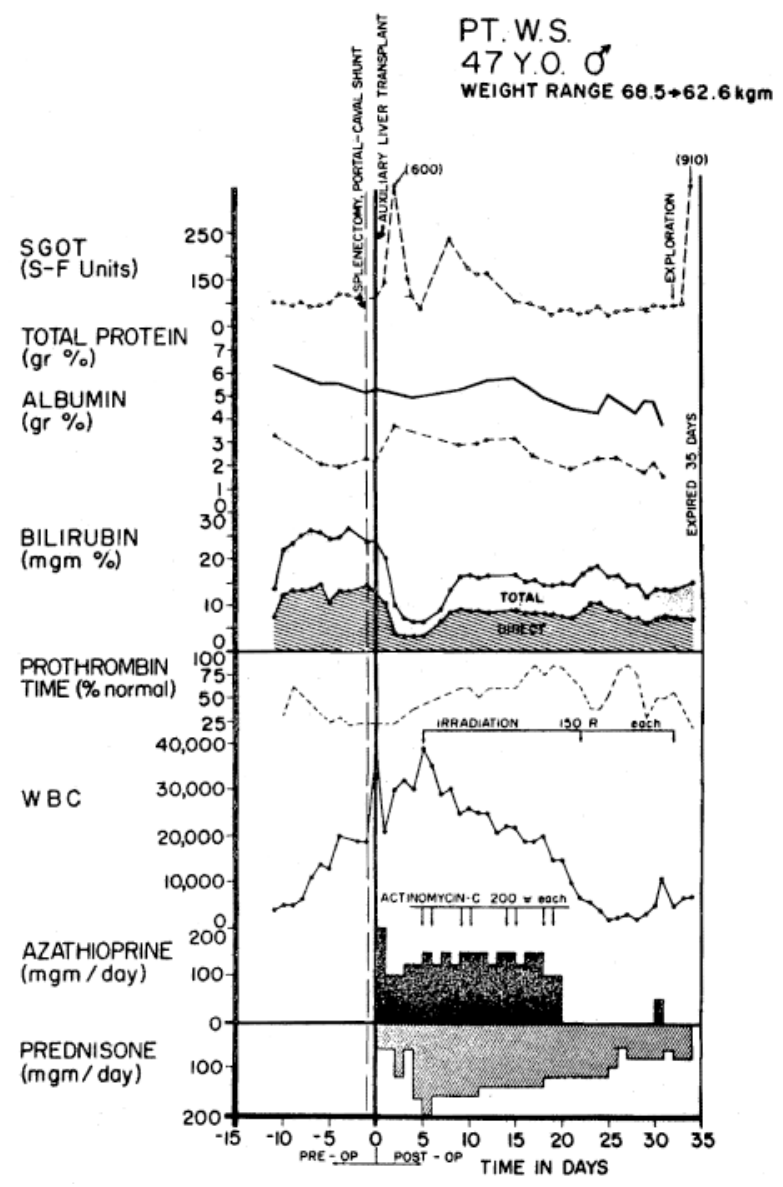

Figure 48.

Clinical course after human auxiliary liver transplantation. The preliminary portacaval shunt was done 1 day before the transplant. The donor was a 12-year-old boy who was killed in an automobile accident. The homograft elaborated bile within a few minutes after its revascularization. There was late deterioration of homograft function, but the primary cause of death was sepsis. 


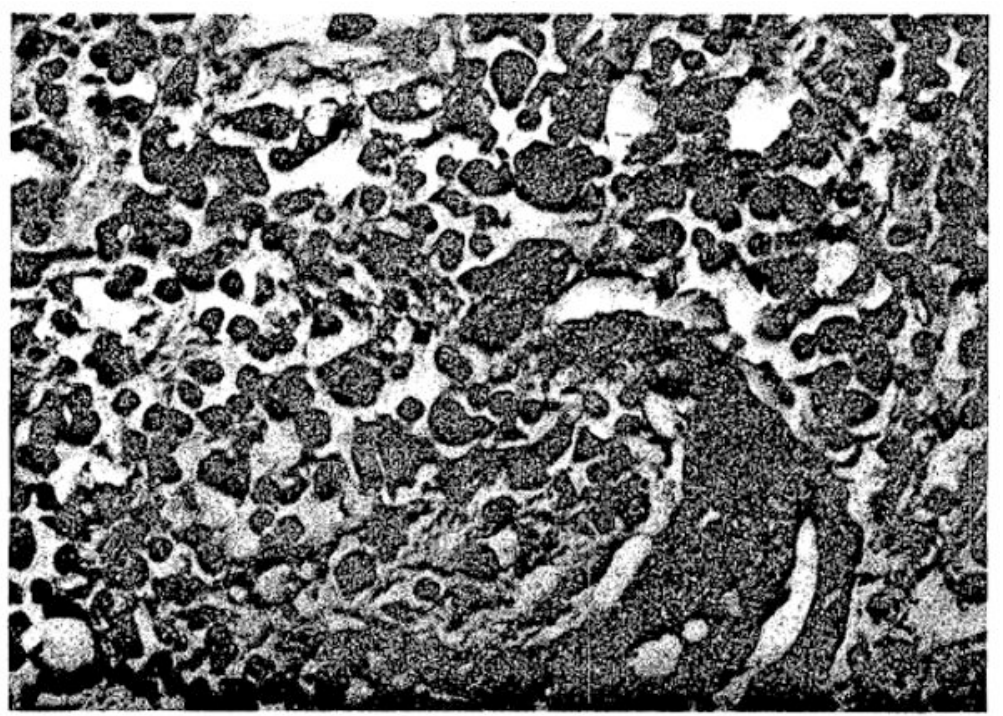

Figure 49.

Auxiliary human hepatic homograft at 22 days. High-power view of a portal tract which is densely infiltrated with mononuclear cells. H \& E. × 600 . 


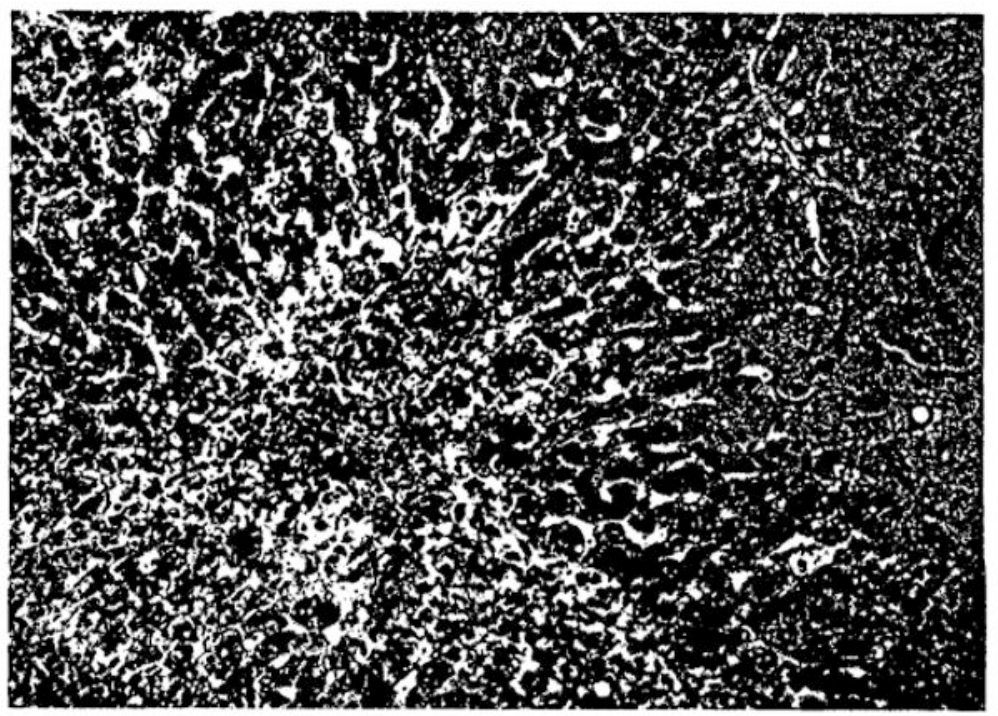

Figure 50.

Auxiliary human hepatic homograft at 34 days. There is necrosis of the centrilobular hepatocytes and fat droplets in the midzonal and peripheral liver cells. $c v$, Central vein; $p t$, portal tract. H \& E. $\times 80$. 


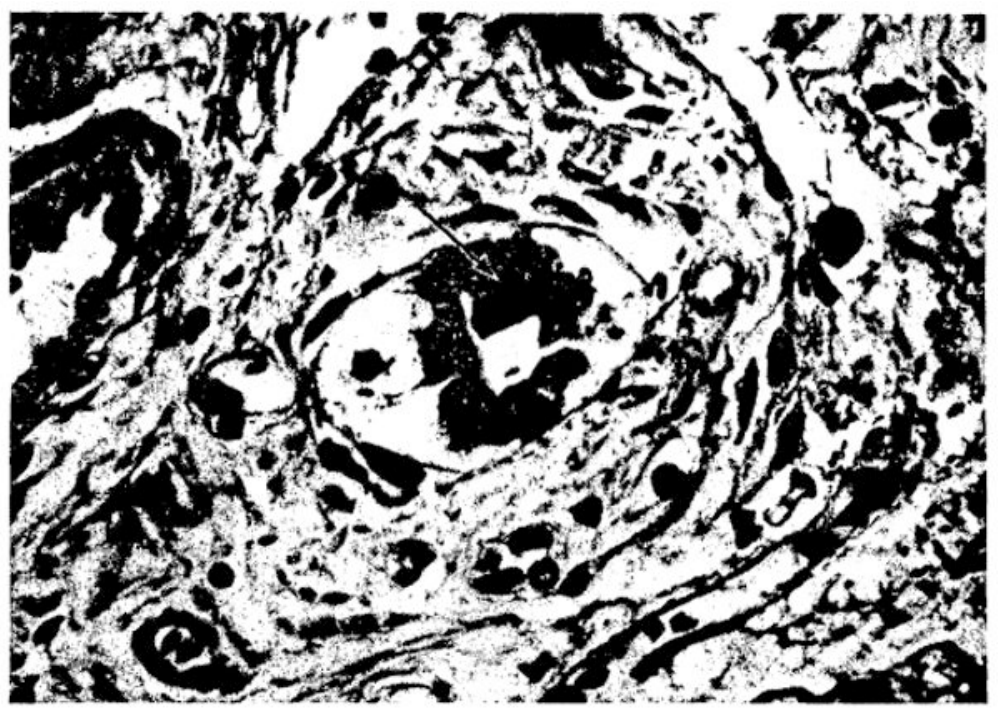

Figure 51.

Intranuclear inclusion (arrow) of cytomegalovirus disease affecting an epithelial cell lining a small biliary duct in the human auxiliary hepatic homograft shown in Figure 50. H \& E. X 600 . 


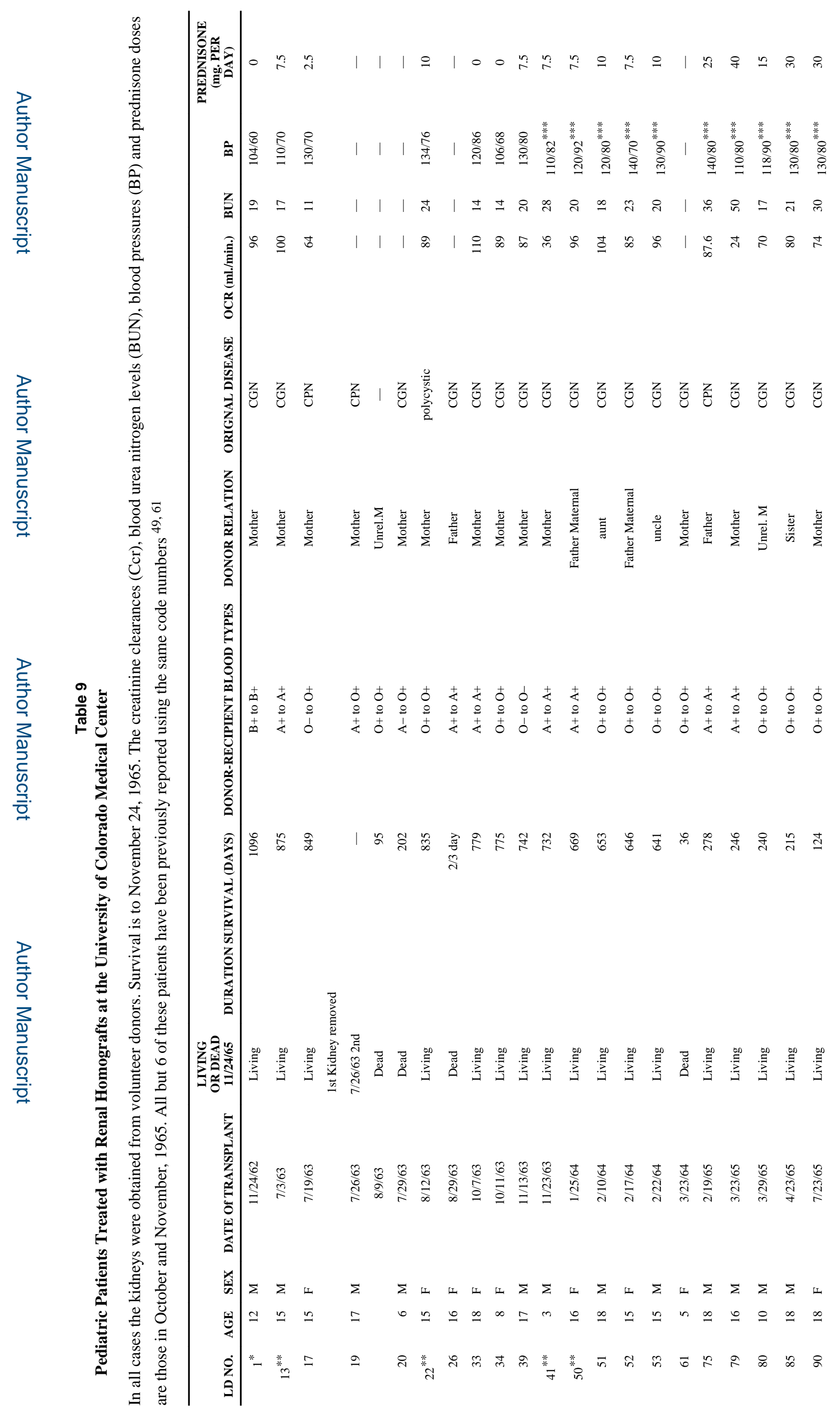




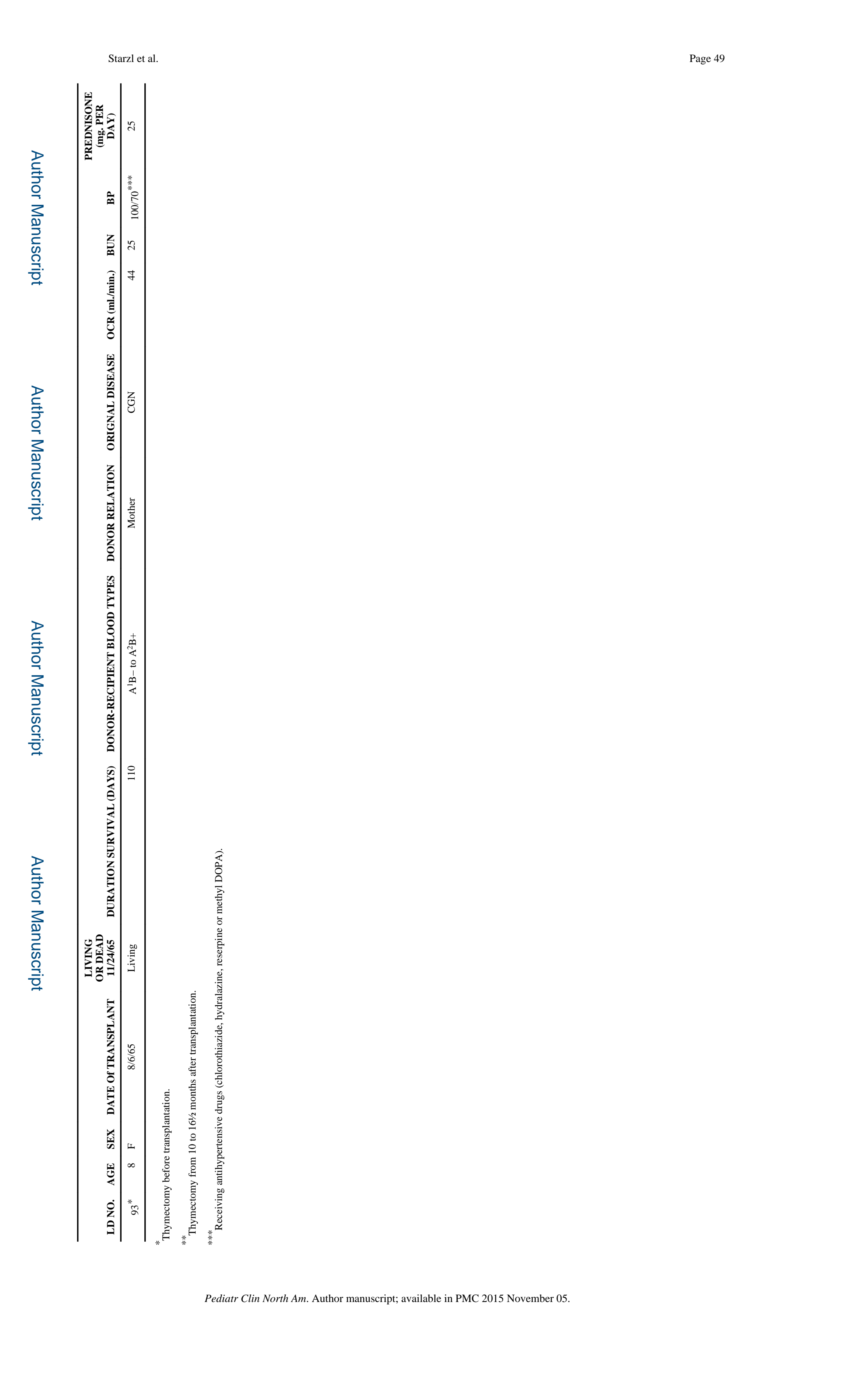


Table 10

Direction of Acceptable Mismatched Tissue Transfer ${ }^{*}$

\begin{tabular}{ll}
\hline O to non-O & Safe \\
RH- to RH+ & Safe \\
RH+ to RH- & Relatively safe \\
\hline A to non-A & Dangerous \\
B to non-B & Dangerous \\
AB to non-AB & Dangerous \\
\hline
\end{tabular}

* $\mathrm{O}$ is universal donor; $\mathrm{AB}$ is universal recipient. 
Table 11

Mortality and Survival in Pediatric Patients Who Received Renal Homotransplantation at the University of Colorado Medical Center

SERIES I
Total number of patients treated 20 months or longer ago: 16
Patients dead: 4
Patients alive as of 11/24/65: 12
20-24 months: 4
2-3 years: 8
SERIES II
Potal number of patients treated from $3 \frac{1 / 2}{2}$ to 9 months ago:
Patients dead: 0
Patients alive as of $11 / 24 / 65: 6$

The operations were performed from November, 1962, to August, 1965, and are divided into an early and late series. No pediatric cases were done between March, 1964, and February, 1965. The long moratorium was imposed so that a better view of the long-term courses could be obtained with the originally treated patients before undertaking the care of fresh cases. The fact that no deaths or serious complications occurred during this period prompted the resumption of the pediatric program at a clinical level. 


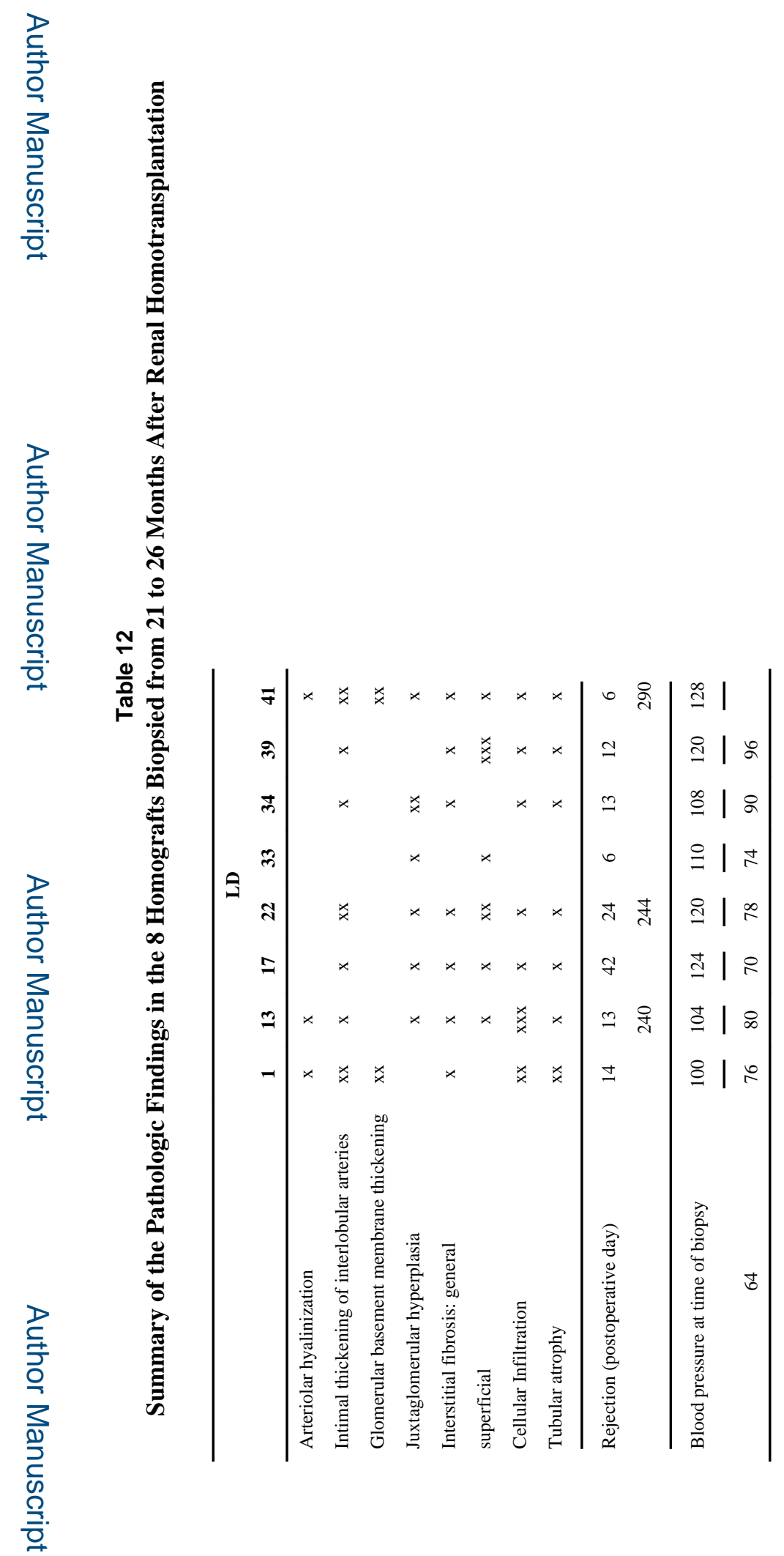

Pediatr Clin North Am. Author manuscript; available in PMC 2015 November 05. 